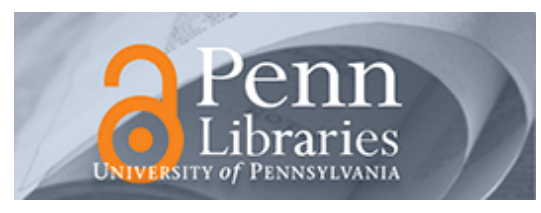

University of Pennsylvania ScholarlyCommons

Finance Papers

Wharton Faculty Research

$10-2014$

\title{
Marriage and Managers' Attitudes to Risk
}

\author{
Nikolai Roussanov \\ University of Pennsylvania \\ Pavel Savor \\ University of Pennsylvania
}

Follow this and additional works at: https://repository.upenn.edu/fnce_papers

Part of the Family, Life Course, and Society Commons, Finance and Financial Management Commons, and the Work, Economy and Organizations Commons

\section{Recommended Citation}

Roussanov, N., \& Savor, P. (2014). Marriage and Managers' Attitudes to Risk. Management Science, 60 (10), 2496-2508. http://dx.doi.org/10.1287/mnsc.2014.1926

This paper is posted at ScholarlyCommons. https://repository.upenn.edu/fnce_papers/152

For more information, please contact repository@pobox.upenn.edu. 


\title{
Marriage and Managers' Attitudes to Risk
}

\begin{abstract}
Marital status can both reflect and affect individual preferences. We explore the impact of marriage on corporate chief executive officers (CEOs) and find that firms run by single CEOs exhibit higher stock return volatility, pursue more aggressive investment policies, and do not respond to changes in idiosyncratic risk. These effects are weaker for older CEOs. Our findings continue to hold when we use variation in divorce laws across states to instrument for CEO marital status, which supports the hypothesis that marriage itself drives choices rather than it just reflecting innate heterogeneity in preferences. We explore various potential explanations for why single CEOs may be less risk averse.
\end{abstract}

Data, as supplemental material, are available at http://dx.doi.org/10.1287/mnsc.2014.1926.

\section{Keywords}

marriage, risk, CEO, investment, volatility, divorce

Disciplines

Family, Life Course, and Society | Finance and Financial Management | Work, Economy and Organizations 
NBER WORKING PAPER SERIES

\author{
STATUS, MARRIAGE, AND MANAGERS' ATTITUDES TO RISK \\ Nikolai Roussanov \\ Pavel G. Savor \\ Working Paper 17904 \\ http://www.nber.org/papers/w17904
}

\author{
NATIONAL BUREAU OF ECONOMIC RESEARCH \\ 1050 Massachusetts Avenue \\ Cambridge, MA 02138 \\ March 2012
}

We thank Andy Abel, Malcolm Baker, Nick Barberis, Effi Benmelech, Terry Burnham, Alex Edmans, Simon Gervais, Itay Goldstein, Todd Gormley, Wayne Guay, Luigi Guiso, Erik Hurst, Michael Lemmon, Ulrike Malmendier, Gregor Matvos, David Musto, Terry Odean, Andy Postlewaite, Michael Roberts, Paola Sapienza, Jose Scheinkman, Antoinette Schoar, Amit Seru, Stephanie Sikes, Todd Sinai, Jeremy Stein, Luke Taylor, Alessandra Voena, and numerous seminar participants at the University of Pennsylvania (Wharton), the University of Southern California (Marshall), the University of California - Berkeley (Haas), Yale Behavioral Science Conference, 2012 Conference on Power, Status, and Influence (PSI) at Northwestern (Kellogg), and 2013 AFA Meeting for useful comments. We gratefully acknowledge support from the Rodney L. White Center for Financial Research (in particular Terker Family Fellowship and Iwanowski Family Fellowship), Wharton Sports Business Initiative, Wharton Entrepreneurship and Family Business Research Centre at CERT, and from Cynthia and Bennett Golub. The views expressed herein are those of the authors and do not necessarily reflect the views of the National Bureau of Economic Research.

NBER working papers are circulated for discussion and comment purposes. They have not been peerreviewed or been subject to the review by the NBER Board of Directors that accompanies official NBER publications.

(C) 2012 by Nikolai Roussanov and Pavel G. Savor. All rights reserved. Short sections of text, not to exceed two paragraphs, may be quoted without explicit permission provided that full credit, including (c) notice, is given to the source. 
Status, Marriage, and Managers' Attitudes To Risk

Nikolai Roussanov and Pavel G. Savor

NBER Working Paper No. 17904

March 2012, Revised February 2013

JEL No. D92,G02,G32

\begin{abstract}
$\underline{\text { ABSTRACT }}$
Status concerns can drive risk-taking behavior by affecting the payoff to a marginal dollar of wealth. If status concerns arise endogenously due to competition in the marriage market, then unmarried individuals should take greater risks. We test this hypothesis by studying corporate CEOs. We find that single CEOs are associated with firms exhibiting higher stock return volatility, pursue more aggressive investment policies, and are not affected by increases in idiosyncratic risk. These effects are weaker for older CEOs. Our results also hold when we use variation in divorce laws across states to instrument for CEO marital status.
\end{abstract}

\author{
Nikolai Roussanov \\ University of Pennsylvania \\ Wharton School, Finance Department \\ 2400 Steinberg-Dietrich Hall \\ 3620 Locust Walk \\ Philadelphia, PA 19104-6367 \\ and NBER \\ nroussan@wharton.upenn.edu \\ Pavel G. Savor \\ Finance Department, Wharton School \\ University of Pennsylvania \\ 3620 Locust Walk \\ Philadelphia, PA 19104 \\ psavor@wharton.upenn.edu
}


Do managers' personal traits matter? A burgeoning recent literature provides ample evidence that individual CEO characteristics impact corporate policies (e.g., see Bertrand and Schoar (2003), Malmendier and Tate (2005)). ${ }^{1}$ One of the key dimensions of heterogeneity is difference in risk attitudes. Such heterogeneity can have important real consequences insofar as it drives corporate investment and $\mathrm{R} \& \mathrm{D}$ activities. But are the differences in risk attitudes permanent, or do they vary over an individual's life-cycle in a predictable way? In this paper, we investigate the role of CEOs' marital status on corporate risk-taking via its effect on the strength of relative wealth concerns.

Relative wealth concerns impact financial decisions by altering individuals' attitudes towards risk. We focus on CEOs, whose preferences are likely to be reflected in corporate investment and financial policies, to the extent that CEO wealth is tied to their firms' financial performance through incentive pay or changes in the value of their human capital. CEO decisions involve large financial stakes and have potentially broad-ranging impact on other agents. $^{2}$ If status concerns influence such decisions, this would represent strong evidence that they are an important factor affecting risk-taking. Furthermore, if status is particularly important for wealthier individuals, as argued by Becker, Murphy, and Werning (2005) and Roussanov (2010a), focusing on a group of individuals who disproportionately represent the upper end of the wealth distribution should help detect the impact of such concerns on financial decisions.

Following Cole, Mailath, and Postlewaite (2001), we develop a model in which concern for relative position arises endogenously from competition for mates in the marriage market. Standard arguments lead to positively assortative matching in marriage markets (e.g.,

\footnotetext{
${ }^{1}$ Benmelech and Frydman (2012), Malmendier, Tate, and Yan (2011), and Schoar and Zuo (2011) trace the impact of the CEOs' earlier life experiences on firm policies and performance. Kaplan, Klebanov, and Sorensen (2008) examine the role of particular types of managerial skills of the prospective CEOs, whereas Adams, Almeida, and Ferreira (2005) and Morse, Nanda, and Seru (2011) focus on the concentration of decision-making power in the hands of the CEOs. Bennedsen, Perez-Gonzalez, and Wolfenzon (2006) and Bennedsen, Nielsen, Perez-Gonzalez, and Wolfenzon (2007) use Scandinavian data to identify exogenous shocks to CEO appointment and termination based on life events. Graham, Harvey, and Puri (2011) directly measure behavioral traits of CEOs and link them to firm actions.

${ }^{2}$ Following Malmendier and Tate (2005), a number of authors have shown that managers exhibiting overconfident behavior engage in more risk-taking - e.g., see Ben-David, Graham, and Harvey (2007). Theoretically, overconfident managerial behavior may be optimal from the firm's standpoint, as explored by Gervais and Goldstein (2007), Gervais, Heaton, and Odean (2011), and Goel and Thakor (2008). Empirically, Hirshleifer, Low, and Teoh (2012) show that managers who exhibit overconfident behavior are more successful in pursuing innovation.
} 
Becker (1973)). In particular, higher wealth individuals are likely to be matched with mates who are highly desirable, in terms of their wealth or other relevant characteristics. ${ }^{3}$ As long as the status payoff - i.e., the improvement in the potential quality of the marital match - raises the benefit of an extra dollar of wealth (beyond its pure consumption value), the matching environment creates an incentive for agents to take more idiosyncratic risk than they would in the absence of the status contest. Since changing mates over time is costly, married individuals will exhibit weaker concern for relative wealth position, all else equal. Thus, our model predicts that single individuals, who are presumably expecting to compete for mates in the future, should have a greater tolerance for risk than married ones, and consequently undertake riskier investments. More specifically, single individuals should assume more idiosyncratic (as opposed to systematic) risk, as such risk makes it more likely they will rank above their peers, and consequently find higher quality mates. Moreover, since wealth and spouse quality are complements in our model, it implies that competition for mates is particularly intense at the top of the wealth distribution, making it particularly suitable for understanding the risk-taking behavior of wealthy individuals such as corporate CEOs.

We test this prediction empirically using a standard sample of U.S. public firms, augmented with a new data set on the marital status of CEOs that we compile from a variety of public sources. We find that companies run by CEOs classified as single in our data set exhibit higher levels of stock return volatility and pursue more aggressive investment policies than otherwise comparable firms, consistent with the hypothesis of greater risk-taking by single managers. These effects are both economically and statistically quite meaningful. A firm run by a single CEO, controlling for a variety of personal and firm characteristics, exhibits stock return volatility that is $3 \%$ higher, and invests $10 \%$ more on average.

As predicted by the model, the difference in volatilities represents varying exposures to idiosyncratic rather than systematic risk. The investment policies vary with marital status for capital expenditures, as well as R\&D spending and acquisitions, which are commonly associated with risk-taking. The effect of marital status is weaker for older managers, which is consistent with our theory, as they are less likely to be competing in the marriage market.

\footnotetext{
${ }^{3}$ Charles, Hurst, and Killewald (2011) present evidence of positive marital sorting based on parental wealth. Chiappori, Oreffice, and Quintana-Domeque (2012) estimate a model of marital matching in which both income/education and physical attributes of a spouse enter into individual's preferences.
} 
Importantly, we control for firm characteristics in our analysis, so that our findings do not simply reflect the tendency of single CEOs to be matched with riskier firms. If we omit firm controls, the relationship between marital status and risk-taking becomes significantly stronger, suggesting that single CEOs indeed are more likely to run relatively risky firms. Moreover, we demonstrate that single CEOs impact firm investment decisions by exploiting within-firm variation in idiosyncratic return volatility over time. We show that while married CEOs reduce investment in response to an increase in idiosyncratic risk (consistent with Panousi and Papanikolaou (2012)), those CEOs who are single do not, confirming that they are less averse to (idiosyncratic) risk. The latter result is based on within-firm variation in idiosyncratic volatility, and therefore cannot be attributed to unobserved heterogeneity driving differences in investment rates across firms.

These results support the hypothesis that single CEOs assume more risk than married ones, and are consistent with our model of CEO status-seeking that is motivated by the desire to find a suitable marriage partner. However, it is also possible that single managers exhibit different risk-taking behavior from married managers even absent status concerns. Individuals who are single at a given age may be inherently more risk-tolerant than those who are married by the same age. It is important to emphasize here that, at least in the simplest portfolio allocation models, more risk-tolerant individuals assume more systematic rather than more idiosyncratic risk, as the latter is not priced in equilibrium and thus is not associated with higher expected returns. Our finding that single CEOs are associated with firms taking on more idiosyncratic risk is therefore not immediately consistent with the innate heterogeneity hypothesis, unless firms have access to idiosyncratic investment technologies that earn positive abnormal returns due to market incompleteness (and CEOs are able to perfectly hedge their aggregate risk exposures, as in Acharya and Bisin (2009)). To further distinguish our explanation from the alternative of innate heterogeneity, we employ an instrumental variable approach.

Our instrument exploits the variation in divorce laws across different states in the U.S., which is very plausibly exogenous to the CEO-firm match and to firms' investment policies. Our basic assumption is that divorce costs should influence an individual's propensity to get married. One aspect of these costs, which should be of particular concern for wealthy 
individuals, is the division of marital property. We therefore distinguish between states where this division is determined by the community property standard and those where it is determined by the equitable distribution standard. The former mandates equal division of assets acquired during marriage between the two divorcing spouses, whereas the latter allows the division to be determined by a judge based on a range of factors, including the relative contributions of the spouses. It is commonly understood that community property is more advantageous for the poorer spouse (e.g., Voena (2011)). Since a CEO should rarely be in this position, he or she should find divorce costlier in community property states. Consequently, all else equal, a CEO working in such a state should be less likely to be married at a given point in time, waiting for a higher quality match. Indeed, this hypothesis is strongly confirmed by the data.

We also provide evidence that a similar pattern holds in the broader U.S. population, but only for wealthier individuals, exactly as our hypothesis implies. This evidence helps validate our instrumental variables approach, as it indicates that the observed effect of community property regime on marital status is unlikely to just reflect other differences across states, such as income distribution, culture, or religion. Crucially, when we use the state divorce law as an instrument for marital status, all our findings continue to hold (and are actually stronger), suggesting the relation between marital status and risk-taking is not simply driven by innate differences between CEOs who are likely to be single single or married.

In addition to status concerns, our results are also consistent with the hypothesis that marriage changes CEO preferences (i.e., it is not the case that married CEOs are innately different than single ones, but that marriage itself changes them). Changing marital status can affect an individual's preferences in a number of ways. Preferences of a married CEO may partially reflect those of their spouse or the need to support a larger family. Alternatively, it may be the case that marriage directly leads to less tolerance of risk: there is evidence that married males exhibit lower testosterone (e.g. Burnham, Chapman, Gray, McIntyre, Lipson, and Ellison (2003)), while high testosterone levels (in both men and women) are often associated with risk-taking behaviors (e.g., Burnham (2007), Sapienza, Zingales, and Maestripieri (2009)), and even appear to predict empire-building behavior among entrepreneurs (Guiso and Rustichini (2011)). While this evidence is consistent with the idea that mating-induced 
status concerns and the associated competitive risk-taking behavior are responses to evolutionary pressures, it may not be directly linked to the marriage market competition in the contemporary human society. Some of our previously discussed tests, based on the distinction between systematic and idiosyncratic volatility, can potentially distinguish between these theories, but we cannot find conclusive evidence favoring one over the other. We show that marital status impacts behavior, but under the status concern interpretation this occurs because marriage is a proxy for how much an individual cares about status, whereas under the marriage-induces-change interpretation the effect of marriage is more direct.

One of the important questions in the literature that studies the impact of managerial characteristics on firm outcomes is whether managers can alter their firms' policies to better suit their personal objectives, or whether the observed differences in the behavior of firms run by different managers simply reflect the matching of executives and firms along the relevant (but difficult to observe for an econometrician) characteristics (e.g., more risk-tolerant CEOs work for riskier firms). While we cannot completely rule out the latter mechanism as an explanation for some of our results, we find it reasonably unlikely, as marital status is not a permanent characteristic of a CEO. Moreover, even if CEOs were always optimally matched to firms, so that their preferences are fully in line with shareholder interests, our findings would still show that riskier firms prefer single CEOs, who are more willing to engage in risky projects.

Apart from understanding manager and firm behavior as such, we are interested in shedding light on the role of status concerns for wealthy individuals, who are likely to be marginal investors in financial markets. Status concerns have been proposed as explanations for gambling behavior (Robson (1992)), local bias in portfolios (Cole, Mailath, and Postlewaite (2001) and DeMarzo, Kaniel, and Kremer (2004)), and other forms of under-diversification, such as entrepreneurial risk-taking (Roussanov (2010a)). Our findings confirm the importance of such concerns by highlighting how they impact even high-stakes decisions. Models of status differ in their predictions as to whether status considerations lead to greater tolerance for idiosyncratic or aggregate risk. In particular, models that feature "keeping up with the Joneses," as in Abel (1990), exhibit conformist, or herding, behavior (e.g., Gollier (2004), DeMarzo, Kaniel, and Kremer (2004)). In contrast, the prediction that competition 
for status leads to greater idiosyncratic risk-taking ("getting ahead of the Joneses"), whether resulting from marital sorting or not, is driven by the feature that the marginal benefit of an extra dollar of wealth is increasing in relative wealth (e.g., Gregory (1980), Becker, Murphy, and Werning (2005)). Therefore, analyzing the differences in attitudes towards idiosyncratic risk by varying the strength of status concerns can shed light on which class of reduced-form relative wealth preferences is empirically relevant, potentially yielding implications for asset pricing and risk sharing.

There is a large literature in evolutionary psychology that links status, mating, and risktaking behavior, especially among males. Overwhelming evidence exists that wealth and socioeconomic status are positively related to men's reproductive success. ${ }^{4}$ Both experimental and survey evidence indicate that mating concerns induce signaling of wealth through conspicuous consumption and financial risk-taking (e.g. see Griskevicius, Sundie, Miller, Tybur, Cialdini, and Kenrick (2007)). This literature also documents greater risk-taking by subjects confronted with situations suggestive of mating or competing for mates (Wilson and Daly (2004) and Baker and Maner (2008)). In the economics literature, Barber and Odean (2000) show that single men display more overconfident trading behavior then single women (or married couples). Household survey data also appears to indicate that for males a change in marital status from single to married is associated with a decrease in the portfolio share invested in stocks and similar risky assets (Love (2010)).

Postlewaite (1998) advocates modeling status concerns as arising endogenously due to non-market interactions (such as marriage and other settings where allocations depend on matching) rather than being hard-wired into preferences. While we pursue the same modeling approach here, one can also interpret our results as consistent with the view that both risktaking and marriage market behavior are determined biologically, and that the link between the two is shaped by evolutionary forces. Evidence in the recent literature indicates that status concerns stemming from marriage market competition are also important for other dimensions of individual consumption and investment decisions. In particular, variation in sex ratios, which determine the intensity of competition among males and females, appears to

\footnotetext{
${ }^{4}$ See Hopcroft (2006), Nettle and Pollet (2008), and Pollet and Nettle (2009), and extensive references therein.
} 
induce variation in the propensity to invest in human and physical capital. Charles and Luoh (2010) exploit the differences in male incarceration rates in the U.S. to identify the effect of marriage market competition on female schooling and labor supply, while Wei and Zhang (2011a) and Wei and Zhang (2011b) use variation in gender imbalances (i.e., the relative number of males to females in the population) across provinces of China to argue that they result in higher savings, greater investment rates, and more economic growth, consistent with the predictions of endogenous status models. Du and Wei (2010) and Du and Wei (2011) use a quantitative model to show that the unbalanced sex ratios in China could also drive its current account surpluses and real exchange rates. These papers focus on how marriage market competition induces individuals to increase their future expected wealth due to the fear of ending up in the lower end of the wealth distribution, and thus being at risk of failing to obtain a suitable marital match. In contrast, our paper is more concerned with how individuals, especially those already in the upper tail of the wealth distribution, attempt to increase the probability of outperforming their peers by assuming more risk. Importantly, such individuals may take on more idiosyncratic risk even if their expected wealth does not increase as a result.

The paper proceeds as follows: Section 1 develops a model of marriage market matching and risk-taking; Section 2 describes our data; Section 3 presents our results using a direct measure of marital status; Section 4 introduces an instrument for CEO marital status; and Section 5 concludes.

\section{Model}

In this section we present a model of matching in the marriage market and investment in order to highlight the interaction between matching-induced status concerns and risk-taking. The model builds on Cole, Mailath, and Postlewaite (1992) and Cole, Mailath, and Postlewaite (2001), who show that competition for mates can induce a concern for relative position even if it does not directly enter individuals' preferences. In our model, such relative wealth concerns can lead to a greater tolerance for risk (e.g., Robson (1992), Becker, Murphy, and Werning (2005)), and especially idiosyncratic risk, as emphasized by Roussanov (2010a). 
The intuition is that competition for mates is akin to an arms race: insofar as potential spouses prefer wealthier suitors, what matters for attaining a spouse of a higher "quality" is how much wealth one has relative to competitors (as long as the notion of spouse quality is the same for everyone). If attaining a higher quality spouse raises one's marginal utility of wealth, then the desire to "get ahead of the Joneses" overcomes risk aversion and leads to greater risk-taking than if matching concerns were absent.

\section{$1.1 \quad$ Environment}

There is a continuum of agents of two types: set $M$ (indexed by $i$ ) of males and set $F$ (indexed by $j$ ) of females, each of measure one. ${ }^{5}$ Each agent derives utility from a market good $c$ and a non-market good $s$ :

$$
u(c, s)=s \log (1+c)
$$

Females are endowed with $f_{j}$ units of the non-market good, distributed according to c.d.f. $H$ on $(0, \infty)$. At the beginning of the period, each male is endowed with $W_{0}>0$ units of a capital good. This good can be converted into the market good at the end of the period by investing it in a combination of two linear technologies: riskless storage at rate $R^{f}$ and agentspecific risky investment that earns a stochastic rate of return $R^{i}$. The market "wealth" of each male at the end of the period is then

$$
W^{i}=W_{o}\left(R^{f}+\theta^{i}\left(R^{i}-R^{f}\right)\right)
$$

where $\theta^{i}$ is the share of initial wealth invested in the risky technology by (male) agent $i$, subject to the constraint that $W^{i}>0$ (this constraint ensures that $c>0$ and, consequently, utility is always increasing in the non-market good). Risky returns $R^{i}$ are distributed independently and identically across agents with a c.d.f. $\Phi$ on $A=\left[R_{\min }, \infty\right) .{ }^{6}$ Let the percentile rank of male $i$ in the resulting equilibrium distribution of end-of-period wealth be denoted

\footnotetext{
${ }^{5}$ We use these labels just for convenience. There is nothing in our model (or in our empirical tests) that requires the two groups to have biological characteristics of their respective sexes.

${ }^{6}$ The assumption of independence is not critical; what is important is that the agent-specific investment opportunities contain some purely idiosyncratic risk so that they are not perfectly correlated across managers.
} 
$G\left(W^{i}\right) \cdot^{7}$

A male and a female jointly consume each good, having matched; i.e., if a male $i$ matches with a female $j$, each of them receives utility $u\left(W^{i}, f_{j}\right)$ at the end of the period. A subset $M_{M}$ having total measure $\lambda_{M} \in(0,1)$ of males, and a set $F_{M}$ of the same measure of females, drawn randomly and independently from their respective distributions, are permanently matched at the beginning of the period. This is meant to capture the idea that people may find their marriage partners early in life, before their investment payoffs are realized. Since all males are ex ante identical while the females are not, they are matched randomly. The remaining subsets $M_{U}$ of males and $F_{U}$ of females enter the matching market at the end of the period, after $W^{i}$ are realized. The relevant equilibrium concept is a stable matching, as introduced by Gale and Shapley (1962), which requires that, given a matching, no male and female would prefer to leave their current matches and pair with each other (see Roth and Sotomayor (1990) for details). Since utility is increasing in both arguments for both males and females, and the two goods are complements, the only stable matching is positively assortative (in $W$ and $f$, respectively), so that the matched male $i$ and female $j$ have the same percentile rank in the respective distributions:

$$
G\left(W^{i}\right)=H\left(f_{j}\right)
$$

Therefore, the equilibrium allocations depend only on the relative status of the males after the realization of uncertainty about the investment projects. The equilibrium matching function produces a pairing

$$
s^{i}=f_{j}
$$

such that

$$
s^{i}=H^{-1}\left(G\left(W^{i}\right)\right)=S\left(W^{i}\right)
$$

Thus, at the beginning of the period, each unmatched male solves

$$
\max _{\theta} E\left[S\left(W^{i}\right) \log \left(1+W^{i}\right)\right]
$$

\footnotetext{
${ }^{7}$ The assumption that only males have access to an investment technology is meant to simplify exposition. One could instead consider a symmetric setting where both "males" and "females" face the same problem.
} 
where $W^{i}$ is subject to the resource constraint (1) above, and taking the equilibrium status function $S\left(W^{i}\right)$ as given. Each exogenously matched male solves

$$
\max _{\theta} E\left[s^{i} \log \left(1+W^{i}\right)\right]
$$

subject to the same resource constraint (1), where $s^{i}$ is the endowment of the female that the male $i$ was randomly matched with at the beginning of the period.

\subsection{Equilibrium}

We focus on a symmetric equilibrium: a solution $\theta^{i}$ to the problem (2) such that $\theta^{i}=\bar{\theta}$ for all $i \in M_{U}$. Since the decisions of matched males solving (3) are neither influenced by nor have an impact on the decisions of other males, they can be omitted from the description of the equilibrium: there is an $\theta_{M}$ such that $\theta^{i}=\theta_{M}$ is satisfied trivially for all $i \in M_{M}$.

In the symmetric equilibrium, the status matching given by the equilibrium distribution of end-of-period wealth is a function of one's own choice $\theta^{i}$ and the choice of all other agents $\bar{\theta}$ (taken by agent $i$ as given). In this symmetric equilibrium, the wealth distribution inherits the properties of the probability distribution of risky asset returns, since

$$
G(W)=\operatorname{Pr}\left[W^{i} \leq W\right]=\Phi\left(\frac{W / W_{o}-(1-\bar{\theta}) R^{f}}{\bar{\theta}}\right)
$$

Assume that the status function $S\left(W^{i}\right)$ is continuously differentiable. Then the first-order condition for the individual investment problem faced by the unmarried male is

$$
E\left[R^{i x}\left(\frac{S\left(W^{i}\right)}{1+W^{i}}+\log \left(1+W^{i}\right) S^{\prime}\left(W^{i}\right)\right)\right]=0
$$

where $R^{i x}=R^{i}-R^{f}$.

For those males whose marriage matches are assigned permanently at time 0 , there is no interaction between investment and matching concerns, and therefore $s^{i}$ is orthogonal to $W^{i}$. Then the first-order condition for the problem (3) of a married male is the standard Euler equation: 


$$
E\left[\frac{R^{i x}}{1+W_{M}^{i}}\right]=0
$$

where $W_{M}^{i}$ is the end-of-period value of the wealth portfolio optimally chosen by agent $i \in M_{M}$ (married at the beginning of the period).

For the males who are active in the matching market at the end of the period, we can write (1.2) as

$$
\begin{aligned}
0= & E\left[R^{i x}\left(\frac{S\left(W^{i}\right)}{1+W^{i}}\right)\right]+E\left[R^{i x} \log \left(1+W^{i}\right) S^{\prime}\left(W^{i}\right)\right] \\
= & \operatorname{Cov}\left(\frac{R^{i x}}{1+W^{i}}, S\left(W^{i}\right)\right)+E\left[\frac{R^{i x}}{1+W^{i}}\right] E\left[S\left(W^{i}\right)\right] \\
& +\operatorname{Cov}\left(R^{i x} \log \left(1+W^{i}\right), S^{\prime}\left(W^{i}\right)\right)+E\left[R^{i x} \log \left(1+W^{i}\right)\right] E\left[S^{\prime}\left(W^{i}\right)\right],
\end{aligned}
$$

so that

$$
E\left[\frac{R^{i x}}{1+W^{i}}\right]=-\frac{1}{E\left[S\left(W^{i}\right)\right]}\left[\begin{array}{c}
\operatorname{Cov}\left(\frac{R^{i x}}{1+W^{i}}, S\left(W^{i}\right)\right)+\operatorname{Cov}\left(R^{i x} \log \left(1+W^{i}\right), S^{\prime}\left(W^{i}\right)\right) \\
+E\left[R^{i x} \log \left(1+W^{i}\right)\right] E\left[S^{\prime}\left(W^{i}\right)\right]
\end{array}\right] .
$$

Suppose the status function is linear:

$$
s^{i}=S\left(W^{i}\right)=\alpha W^{i}
$$

so that $S^{\prime}\left(W^{i}\right)=\alpha$ is a (positive) constant and $\operatorname{Cov}\left(R^{i x} \log \left(1+W^{i}\right), S^{\prime}\left(W^{i}\right)\right)=0$. Then (5) implies

$$
E\left[\frac{R^{i x}}{1+W^{i}}\right]=-\frac{1}{E\left[S\left(W^{i}\right)\right]}\left[\operatorname{Cov}\left(\frac{R^{i x}}{1+W^{i}}, S\left(W^{i}\right)\right)+E\left[R^{i x} \log \left(1+W^{i}\right)\right] E\left[S^{\prime}\left(W^{i}\right)\right]\right]
$$

Consequently, for single males this Euler equation implies an inequality

$$
E\left[\frac{R^{i x}}{1+W_{U}^{i}}\right]<0
$$

that must satisfied by the optimal wealth portfolios $W_{U}^{i}$ for all $i \in M_{U}$ (unmarried at the 
beginning of period). By comparison with the Euler equation (4), this inequality states that the expected excess return on the idiosyncratic risky project, risk-adjusted using the stochastic discount factor of a married investor evaluated at the optimal wealth of a single investor, is negative. That is, the single investor's optimal portfolio exhibits a higher allocation to the idiosyncratic asset than that optimally chosen by the married agent. In other word, agents who are active in the marriage market invest more in the idiosyncratic risky project than those who are married at the beginning of period.

What is the mechanism behind this result? If the idiosyncratic project enjoys a high return, this not only raises the wealth (and therefore consumption) of the agent, but also increases the equilibrium quality of his match, since the wealth of other agents is unaffected, and so it is easier for him to beat the competition. Thus, $S\left(W^{i}\right)$ increases, which in turn raises the marginal utility of consumption. Since wealth becomes relatively more valuable in the high $R^{i}$ state, this idiosyncratic asset is less risky from the perspective of an agent who is active in the marriage market than it is from the perspective of an exogenously-matched agent, who does not care about relative position. If the risky asset realization was common to all agents, however, this effect would not arise. Since all males are ex ante identical, a higher return on the common asset does not alter their relative positions and hence has no impact on status and, consequently, match quality.

\subsection{Special cases and extensions}

The model prediction above was derived under the simplifying assumption (6), which states that the reduced form equilibrium status/matching function is linear in male agent's wealth. Under what conditions is the status function linear? The following simple examples provide sufficient conditions:

1. female good is distributed uniformly on $\left[f_{\min }, f_{\max }\right]$ and the equilibrium distribution of wealth is uniform (which is the case if $R^{i x}$ is uniformly distributed on $\left[R_{\min }, R_{\max }\right]$ );

2. the distribution of the female non-market good coincides with the equilibrium distribution of male wealth, $H(x)=G(x)$ for all $x$; this situation is relevant also if the 
problem is completely symmetric, i.e. the females face an investment problem identical to that faced by the males.

What if $S$ is not linear? Then the sign of $\operatorname{Cov}\left(R^{i x} \log \left(1+W^{i}\right), G^{\prime}\left(W^{i}\right)\right)$ is ambiguous and depends on the shape of the status/matching function $S$, which, in turn, depends on the equilibrium distribution of wealth $G$. In particular, if $S$ is convex, the latter covariance is negative and the same conclusion as above holds. However, if $S$ is concave, the conclusion is ambiguous and potentially depends on the specific parameterization of the model.

The feature of the model that yields the prediction of greater risk-taking by single managers under a broad set of conditions is the complementarity between the male and the female good (i.e., the fact that $u_{c s}>0$ ). This feature is intuitive: a higher quality spouse raises one's own marginal utility of consumption. For example, a spouse with a higher level of "sophistication" may influence one's tastes in a direction that demands purchase of more expensive consumption goods.

The complementarity assumption is not crucial. For example, Cole, Mailath, and Postlewaite (2001) consider a setting in which utility is separable in the market and non-market good, and show that if the status/matching payoff is convex in market wealth, the same result as here obtains (agents take more idiosyncratic risk than in the absence of matching). However, if utility is sufficiently concave over the non-market good, the opposite prediction obtains - the agents "herd" towards common projects (Roussanov (2010b) describes in detail the conditions under which these predictions hold).

A model can be easily generalized to accommodate other margins that have an effect on wealth accumulation, such as a choice of effort vs. leisure or intertemporal consumptionsaving decisions. Since the status payoff that comes from the marriage market competition provides an additional benefit of wealth, the key prediction of the model carries over under fairly general conditions: unmarried individuals invest more than married ones. This is because the relative position concerns induced by matching are a form of an arms race: single individuals competing for mates are lead to accumulate more resources than they would for consumption purposes alone. However, unlike other models of relative wealth concerns based on marriage market interactions, such as Cole, Mailath, and Postlewaite (1992) and Wei and Zhang (2011a), our emphasis is not on pure wealth accumulation, but 
rather on the risk-taking that leads to extreme outcomes and increased wealth dispersion. While CEOs do not necessarily compete with one another for mates, they do not compete with an average person. Rather, they likely compete with other wealthy and highly visible individuals, such as top entrepreneurs, entertainers, and asset managers, who dominate the highest wealth percentiles (Kaplan and Rauh (2010)). Indeed, our model emphasizes that that the payoff to the relative position is the highest in the right tail of the distribution (due to the complementarity between wealth and spouse quality), leading to increased risk-taking.

\subsection{Discussion of Implications}

We show that under a set of plausible conditions individuals who expect to compete in the market for mates exhibit greater risk-taking than those who do not, including those who are already matched. We aim to test this prediction of the model by analyzing differences in risk-taking between single and married managers. The intuition is that for single individuals marriage market competition is more acute than for those already married (even if the matches are not expected to be permanent, as long as divorce and re-matching are costly). The model is deliberately simple in that it compares people who make investment decisions before competing in the marriage market to those who invest after being exogenously matched. The way to interpret this assumption is that the probability of being married at a given point in time depends on luck (e.g., in meeting a suitable partner) as well as relative wealth.

\section{Data}

\subsection{CEO Characteristics}

We collect the names, biographical information, and compensation of all CEOs covered by ExecuComp in the 1993-2008 period. We then research their marital and family status using a variety of public sources, such as the Marquis Who's Is Who in Finance and Industry, the SEC insider filings, and various media mentions. The ultimate goal of this effort is to establish whether a particular CEO was married or single during his tenure. Unfortunately, 
we can obtain the actual marriage dates only for a small minority of CEOs, which means that for the bulk of our sample we have to rely on an indirect approach. More specifically, for those CEOs for whom we can find no dates, we start with the assumption that they are single, and then change their status if we find information indicating the opposite. ${ }^{8}$ Any CEO who is ever mentioned as being married but the exact dates of marriage are not available is coded as married throughout his or her tenure. This means that some CEOs who were divorced or whose spouses were deceased will be wrongly counted as married. However, there also exists an offsetting bias. Since we require evidence to classify a CEO as married, those CEOs who are not prominent enough to warrant mention in our sources (or those who are very private with regards to their personal information) will appear in the data as single even if they are actually married. While we perform a comprehensive search for all CEOs, it is inevitable that we miss some. Furthermore, some CEOs may be involved in marriage-like relationships but not formally married, and their status for our purposes should be classified as married but will not be.

The net effect of these biases cannot be determined with much certainty, but we are hopeful our data is not too unrepresentative. Table 1 shows that in terms of CEO-year observations married CEOs account for $84 \%$ of our sample. If we just consider each individual CEO, single ones make up $20 \%$ of our sample. According to the U.S. Census data, $70 \%$ of men in the 35-59 age range were married in 2000. This group represents most of the CEOs in our sample, so it would appear that we overestimate the number of currently married CEOs. ${ }^{9}$ But CEOs are also much wealthier than typical Americans, and wealth may be positively correlated with the probability of being married.

In order to confirm that the proportion of single CEOs in our data is reasonable, we use data from the Survey of Consumer Finances (SCF) for the year 2001, which is roughly in the middle of our sample period. The SCF oversamples wealthy households, and therefore is more likely than the Census to accurately capture the demographic to which the CEOs in our

\footnotetext{
${ }^{8}$ Our information sources report that a CEO is married reasonably frequently, but almost never directly report that one is single, so that we cannot start with the assumption that a CEO is married unless we find evidence to the contrary.

${ }^{9}$ At the same time, we may be underestimating the proportion of CEOs who were married at any point in time (though not necessarily during their tenure). In the Census data, of the men falling in the 1950-1954 birth cohort, $89 \%$ had been married at some point before reaching the age of 50 .
} 
sample belong. It also does not apply systematic top-coding to income and wealth variables, unlike most other commonly used survey datasets, and therefore provides reliable evidence on the financial position of the wealthiest households (see Kennickell and Lane (2006)). ${ }^{10}$ We estimate a logistic regression predicting that the head of household in the SCF is single using the following specification:

$$
\operatorname{Pr}(\text { Single })=\Phi\left(\alpha+\beta \times \text { Wealth }+\gamma \times \text { Income }+\delta \times A g e+\zeta \times \frac{A g e^{2}}{100}\right)
$$

where Single is a dummy variable that equals one if the head is unmarried, Age is the head's age, Income is the annual household income, and Wealth is a measure of household wealth. We use two wealth measures: one is the total household net worth (total assets minus total liabilities), and the other is the value of holdings concentrated in the single largest risky asset. The latter wealth variable (see Roussanov (2010b) for details on its construction) is meant to mimic our proxy for CEO wealth, which is based on holdings of own-company stock and options. We do not use SCF population weights, which are supposed to address the issue of oversampling of wealthy households, as we are interested in capturing the relation precisely for such households rather than the U.S. population as a whole.

Table 2 presents the regression results, together with the implied probability of being single computed for the median CEO in our sample. This probability is calculated based on the median CEO wealth of $\$ 13.8$ million, median annual CEO compensation of $\$ 2.2$ million, and median CEO age of 55 years. The implied probabilities for various specifications fall in the 11 to $20 \%$ range, which is not too far from the proportion of CEOs we classify as single in our sample. Consequently, we conclude that our measure of marital status is reasonably accurate, at least in the sense that we do not greatly overestimate or underestimate the number of unmarried CEOs.

While there is a number of CEOs who are divorced in our sample, we do not explicitly consider divorced CEOs 'single', as it is not obvious from the perspective of our model that we should. Divorce is not an exogenous shock that simply changes an individual's marital

\footnotetext{
${ }^{10}$ The SCF does explicitly drop all households/individuals listed in the Forbes 400 list of the wealthiest people. Since this list covers only a subset of the CEOs in our sample, the overlap between the two groups is likely sufficiently large to make reliable inferences.
} 
status. It is actually a result of a decision by one (or both) spouses that takes into account the value of re-entering the marriage market. In particular, the CEO's decision prior to divorce may take into account the matching considerations arising from a potential re-marriage. For example, if a CEO's wealth has increased enough since marriage, the prospect of improving the marital match may increase risk-taking prior (and potentially leading) to divorce. On the other hand, even if divorce is costly, if a CEO's wealth falls enough, the spouse may prefer to terminate the marriage and seek a better match in the re-marriage market, which will reduce the CEO's risk tolerance after marrying.

If we wrongly characterized marital status of some CEOs, this would not constitute a problem for our analysis, as long as this effect was uncorrelated with anything else. The problem is that this may not be true for CEOs who are married, with no public information documenting their status. Such CEOs are likely to be less prominent than their peers and could potentially be associated with younger, riskier firms. This effect may explain risk-taking attitudes of managers we classify as 'single', without any actual effect of marital status. For example, Malmendier and Tate (2009) find that "superstar" CEOs exhibit different behaviors than their less prominent counterparts. This may represent a serious problem for our analysis, which we address in several ways. ${ }^{11}$

First, in our regressions we use as controls observable measures that are likely to be correlated with both the degree of prominence of a company and its riskiness, such as firm size, market-to-book ratio, and age. Second, we explicitly control for the effect of prominence on our classification of CEOs as married or single by constructing measures of frequency of CEO and company media mentions. Specifically, we use Factiva Dow Jones database to count the number of news stories mentioning the CEO and/or the company associated with each of the observations during our sample period. We use these measures to control for the effect of prominence on risk-taking in our analysis. While these controls do appear to capture some variation in firm risk, their inclusion does not affect our results.

\footnotetext{
${ }^{11}$ Such "superstar status" itself could be viewed as a type of status payoff that could induce risk-taking. Shemesh (2010) presents some evidence that achieving this status leads CEOs to reduce subsequent risktaking.
} 


\subsection{Other Control Variables}

We augment our CEO data set with data from COMPUSTAT and CRSP, which we use to construct measures of corporate risk-taking and the necessary control variables. The various variables we use are defined below (all numbers except ratios are in millions). ${ }^{12}$

Total investment (Investment) is capital expenditures (CapEx) plus acquisitions minus asset sales (Net Acquisitions) plus R\&D expenditure $(R \& D)$ plus advertising expenditure (Advert.), scaled by net property, plant \& equipment (PP\&E). This is a more comprehensive measure than used in most of the literature, but we believe R\&D and advertising expenditures should be counted as investment for our purposes, as they do reflect a firm's risk-taking (Guay (1999) uses R\&D expenditure as a proxy for CEO risk-taking). We also consider the individual components of investment separately (scaled by PP\&E). Total volatility is computed as the annualized volatility of a firm's monthly stock returns over the previous year. Idiosyncratic volatility is calculated as the annual volatility of the residuals of the firm's stock returns regressed on the CRSP value-weighted stock market portfolio return.

Firm size $(\log A)$ is the $\log$ of its total assets. Book equity $(B E)$ equals stockholders' equity; if that item is missing in COMPUSTAT, then it is common equity plus preferred equity; and if those items are unavailable as well, then it is total assets minus total liabilities. Market-to-book ratio $(M / B)$ is the ratio of the market value of assets relative to their book value, where the market value of assets is the total value of assets minus book value of equity plus market value of equity. Cash flow $(C F)$ equals earnings before extraordinary items plus depreciation \& amortization, scaled by net PP\&E. Book leverage (Leverage) equals the sum of long-term and current debt divided by the sum of long-term debt, current debt, and book equity. Firm age is computed with respect to the first year it appears in COMPUSTAT. All firm-related variables (except size and book equity) are winsorized at the 1\% and $99 \%$ levels.

We also use information available in ExecuComp on the relevant characteristics of managers. CEO wealth (log wealth) is the log of CEO's total holdings of own company stock and options, which we use as a proxy for total CEO wealth. Age and Tenure are the CEO's age

\footnotetext{
${ }^{12}$ We include in our sample all firms for which we have the necessary data. Our results continue to hold if we exclude financial firms.
} 
and his tenure with the firm, as of the current year. The Factiva-based measures of CEO and firm prominence are each defined as the logarithm of the total number of their media mentions during our sample period. For CEOs, we only count news stories that are explicitly related to the firm they run, in order to avoid greatly exaggerating the prominence of CEOs with common names.

\section{CEO Marital Status and Risk-Taking}

\subsection{Overview}

Table 1 presents the main summary statistics for our data, grouping firms based on the marital status of their CEOs. It confirms that our classification produces intuitive results: married CEOs are on average somewhat older and, consistent with the theory that relates marital market competition with wealth, richer (insofar as we can proxy their wealth with the value of their holdings of the company's stock and options). This first look at the data also supports our main hypothesis: firms managed by CEOs whom we classify as single display markedly different characteristics. Such firms have higher investment and experience greater return volatility, both of which measures should be related to the amount of risk associated with a firm. The differences are highly significant, both economically and statistically. Return volatility of single CEO firms is $24 \%$ higher, and a t-test for the difference produces a tstatistic of about 14 (untabulated). Investment is $69 \%$ higher for such firms relative to those run by married CEOs, with a t-statistic of 13 for the difference.

These differences appear to be quite dramatic, but single CEO-run firms are also on average smaller, younger, and potentially faster-growing, as indicated by their higher marketto-book ratios. Since both small and growth firms tend to invest more and have more volatile returns, it is important to control for these characteristics. We therefore run a variety of regression specifications with investment and return volatility as independent variables:

$$
\text { RiskTaking }=\alpha+\beta \times \text { Single }+\gamma \times X+\delta \times Y+\zeta \times(\text { Single } \times \tilde{Y}),
$$

where RiskTaking is our measure of risk-taking, Single is a dummy variable equaling one if 
the CEO is unmarried and zero otherwise, $X$ is a set of firm characteristics, and $Y$ is a set of CEO characteristics (the specific variable definitions are given above), and $\tilde{Y}$ are the same characteristics that have been demeaned. All our regressions also include industry (based on the Fama-French 49-industry classification) and year fixed effects. We compute t-statistics using clustered standard errors (by firm).

\subsection{Single CEOs Run Riskier Firms: Examining Return Volatility}

Tables 3 and 4 present regression results for the total (annualized) volatility of firm stock returns and for the idiosyncratic component of volatility, respectively. The coefficient of most interest is the dummy variable Single.

Do firms led by single CEOs experience greater return volatility, controlling for firm characteristics? Results reported in Table 3 show that firms run by single CEOs do exhibit more volatile returns. This difference is statistically significant (t-stat $=2.3$ in columns 4 and 5, which feature the most comprehensive sets of control variables) and economically meaningful, with the coefficient magnitude suggesting about a $3 \%$ difference. $^{13}$ In column 1, we control for various firm characteristics that may be related to stock return volatility. Importantly, all these firm-level control variables have the expected effect: firms with low cash flows, firms with high market-to-book ratios, small firms, firms with high leverage, and young firms have more volatile stock returns.

Since married and single CEOs also have different personal characteristics, in column 2 we add controls for CEO characteristics, such as age and tenure, and the interactions between those characteristics and the single status dummy variable (characteristics variables in the interaction terms are always demeaned). Both age and tenure are significantly negatively related to firm risk. Older CEOs tend to be more conservative, which is also consistent with the relevance of positional concerns declining with age, since the value of marriage is likely to decline if there are fewer years over which one can enjoy its benefits. ${ }^{14}$ Furthermore, people who remain single at an older age are more likely to be those who do not value the

\footnotetext{
${ }^{13}$ Computed as 0.012 (Single coefficient magnitude) divided by 0.370 (mean return volatility for firms run by married CEOs).

${ }^{14}$ Levi, Li, and Zhang (2010) document more aggressive deal-making behavior among younger CEOs, and argue that it is driven by their higher testosterone levels.
} 
benefits of marriage highly, and therefore for whom matching concerns are less relevant. Such considerations imply that we need to control for these CEO characteristics, as they are also correlated with the probability of being married. For example, older CEOs may invest more cautiously and are more likely to be married, which would confound the effect of marital status if appropriate controls are not included.

Introducing manager age and tenure in column 2 reduces the coefficient on Single from 0.012 to 0.008 and the t-statistic from 2.64 to 1.76 relative to the specification in column 1 , which only includes firm-level controls. This is due to the fact that both CEO age and CEO tenure have a negative effect on volatility.

In column 3, we add our controls for CEO and firm prominence. The coefficient on CEO prominence is large and significant ( $\mathrm{t}$-stat $=3.12$ ), which is consistent with previous work (e.g., Malmendier and Tate (2009)). Our main finding that single CEOs invest more remains unaltered. In fact, it turns out that the effect of prominence, if anything, works against us, since it is the CEOs of riskier firms who appear to have higher rates of media mentions, and are therefore less likely to be mistakenly classified as single. Consequently, the Single coefficient actually becomes larger, with a higher statistical significance (t-statistics are above 2 in all of the specifications where this control variable is included).

Our model predicts that the relative wealth concerns induced by marriage market competition make single managers less averse to idiosyncratic risk, since common shocks that affect everyone equally do not change relative ranking. Indeed, our empirical findings hold - and are actually stronger - for idiosyncratic volatility, consistent with the model's predictions. These findings are presented in Table 4. In fact, all of the effect of marital status on volatility is driven by idiosyncratic volatility. ${ }^{15}$ Alternative mechanisms generating differences in risk aversion between single and married CEOs, such as life-cycle changes in consumption commitments and preference aggregation within a family, are unlikely to drive our findings, unless managers are able to perfectly hedge all of the aggregate risk exposure inherent in their compensation.

In columns 4 and 5 of Tables 3 and 4, we add as a control institutional holdings of company

\footnotetext{
${ }^{15}$ Unreported regression results for total volatility controlling for its idiosyncratic component are available upon request.
} 
stock, obtained from Thomson Reuters database of $13 \mathrm{f}$ filings. We use institutional holdings as a proxy for the quality of a firm's corporate governance, under the assumption that firms with higher institutional ownership will be more responsive to shareholders. We introduce this variable to test whether greater shareholder control attenuates the effect of marital status, perhaps by making it harder for single CEOs to undertake overly risky investments. Firms with greater institutional ownership are indeed less risky (the coefficient is negative and statistically significant). Moreover, the interaction with the Single variable is negative and statistically significant, indicating that better governed firms may moderate the tendency of single managers to increase risk. This effect is particularly strong for idiosyncratic volatility, albeit it is slightly weaker in specifications listed in column 5 of each table that features joint industry $\times$ year fixed effects (rather than the separate industry and year fixed effects employed elsewhere).

Controlling for firm characteristics helps isolate the potential effect of manager's preferences on firm performance, but it understates the explanatory power of our model with respect to the managers' individual behavior. In particular, insofar as potential managers choose to work for firms that match their risk preferences, single managers are likely to choose to work for companies exhibiting greater exposure to (idiosyncratic) risk than married managers. When we exclude controls for firm characteristics (column 6), the results become much stronger: return volatility of firms run by single CEOs is $16 \%$ higher, and the t-statistic for the difference is 7.83. This is not surprising from the perspective of our model, as single CEOs are more likely to be matched with riskier firms if they are less averse to (idiosyncratic) risk. But they also undertake more risks even when we control for this tendency (as results in columns 1-5 show).

\subsection{Where Does Risk Come From: Evidence on Firm Investment}

What drives differences in riskiness between firms run by single and married CEOs? Our hypothesis implies that besides opting to work for inherently riskier firms, single CEOs may steer their companies towards projects with greater idiosyncratic risk, as well as generally pursue more aggressive investment policies. In order to test this prediction we examine the

effect of marital status on investment. Tables 5, 6, and 7 present regression results for vari- 
ous forms of firm investment (total investment, net acquisitions, and R\&D plus advertising expenditure, respectively).

Column 1 of Table 5 shows that the Single coefficient is positive and statistically significant (t-stat $=2.35)$. Its magnitude suggests an economically very meaningful effect of marital status: single CEOs invest 0.09 more than their married counterparts (relative to the sample mean of 1.00). In this specification, we control just for different firm characteristics that are known to be correlated with investment. The coefficients on these controls are all the same as documented in previous work. Firms with high cash flows, growth firms, small firms, and firms with high past investment tend to invest more. ${ }^{16}$ These are well-known correlations, and the fact they hold in our sample reassures us that it similar to those used in other studies.

The inclusion of CEO age and tenure reduces the Single coefficient somewhat, but it remains statistically significant $(\mathrm{t}-\mathrm{stat}=1.71)$. And its magnitude still indicates a large effect: a firm with a single 45-year old CEO with a tenure of five years will have investment that is on average 0.26 higher than that of the same firm with a married CEO, while the sample mean for firms with married CEOs is 0.90. In other words, investment of such firms is $29 \%$ higher, which is a very substantial economic difference.

Interestingly, the interaction coefficient between Single and Age is negative, which means that the impact of marital status on investment is less important for older CEOs. This is consistent with the basic motivation underlying our study. If single CEOs indeed choose to invest more because they are less risk-averse due to their competing in the marriage market, we would expect this tendency to be less pronounced for older CEOs, as presumably the benefits of a prospective future marriage are lower later in one's life. Further, given some underlying heterogeneity in the individual desire to get married, as more people are likely to be married in older age groups, those who remain single are likely to be those who are less interested in marriage and therefore for whom the matching-induced status motive is inoperative.

Moreover, this negative interaction between the effects of age and marital status also suggests that the driving force behind our results may not be purely a selection effect, whereby

\footnotetext{
${ }^{16}$ Our results do not change if we use investment during the previous CEO's tenure as a control instead of lagged investment.
} 
CEOs who prefer to stay single are fundamentally different (e.g., in terms of their risk attitudes) from those who marry. If that were the case, then the effect of marital status would be less likely to decrease with age. In fact, it would likely increase, as at older ages the single group would be predominantly populated by people with particularly strong "aversion" to marriage.

Our results do not change if we add controls for firm region, or if we use a different industry classification scheme. ${ }^{17}$ They also are stronger if we focus just on R\&D and advertising expenditures (Table 7), which arguably capture firm risk-taking more accurately, as they are commonly perceived as representing especially risky activities. The results are somewhat weaker for Net Acquisitions (Table 6), likely due to the fact that a lot of smaller firms do not make any acquisitions, but even there the effect is statistically significant in a specification with the most comprehensive set of controls (including industry $\times$ year fixed effects) in column 5 .

Does institutional ownership mitigate the aggressive investment policy of single CEOs? The institutional holdings coefficient is positive and significant for total investment and acquisitions (and essentially zero for R\&D and advertising). However, the coefficient on the interaction term between holdings and Single is not significant, and our findings on the effect of Single on investment remain the same as before once these controls are included, (and are even boosted by the inclusion of industry $\times$ year fixed effects in column 5 ).

As mentioned before, we are not taking a stand in this paper on whether CEOs alter firm decisions to meet their own objectives or are just matched to firms along all their relevant characteristics. In order to explore how much of a role CEO-firm matching plays, in the last column we omit any firm characteristics from our regressions. Consequently, we are comparing single and married CEOs just controlling for their personal characteristics. Under that specification, the Single coefficient for Total Investment grows dramatically to 0.45 (from 0.09), with a t-statistic of 5.23, and even the coefficient for Net Acquisitions is statistically significant with a t-statistic of 2.59 (Table 6). Similarly to the return volatility results in the previous section, these findings suggest that riskier firms are strongly associated with single CEOs, perhaps because these CEOs are more willing to accept risks. However, even

\footnotetext{
${ }^{17}$ Those results are available upon request.
} 
if we control for this selection effect (in columns 1-5), single CEOs still assume greater risks than married ones. Results in column 5 are probably the most conservative estimate of the difference between married and single CEOs, to the extent that our (potentially imperfect) controls capture all of the relevant firm characteristics, whereas those in column 6 represent the most aggressive estimate.

It is not surprising that firms that invest more are also riskier. Unfortunately, we do not have enough observations of CEO marital status changes (or changes between married and single CEOs) to establish whether firm risk and investment also change when they occur. However, we can exploit the impact of within-firm variation in risk on investment to explore futher the role of CEO marital status. Panousi and Papanikolaou (2012) find that an increase in idiosyncratic volatility decreases corporate investment, which is consistent with the effect of managerial risk aversion, since CEOs cannot hedge purely idiosyncratic (firm-specific) risk. Our model predicts that single CEOs have higher tolerance for idiosyncratic risk. As a consequence, we should expect to see a much weaker effect of lagged idiosyncratic volatility of the firm's stock returns on investment among firms whose heads are single. To test this hypothesis, we estimate the following regression specification:

$$
\text { Investment }_{t}=\alpha+\beta \times \text { Single }+\gamma \times I d V o l_{t-1}+\delta \times\left(\text { Single } \times I_{\text {Id }} \text { ol }_{t-1}\right)+\zeta \times X,
$$

where $I d V$ ol $_{t-1}$ is lagged idiosyncratic volatility of the firm's stock returns and $X$ is a set of firm and CEO characteristics used as controls. Importantly, the latter includes firm as well as year fixed effects, as we are interested in within-firm effect of risk on investment. Results are reported in Table 8. Consistent with the evidence in Panousi and Papanikolaou (2012), we document a robustly negative and statistically significant effect of $I d V o l_{t-1}$ on total firm investment, with coefficients of -0.175 without any controls other than fixed effects and around -0.330 when various combinations of controls are added, and t-statistics ranging between -3 and -6. Furthermore, while there is no statistically significant effect of Single itself on withinfirm variation in investment, there is a strongly positive effect of the interaction between Single and the idiosyncratic volatility measure on investment. This effect is essentially of the same magnitude as the effect of volatility itself, with coefficients ranging between 0.216 
and 0.319 and t-statistics between 2.2 and 3.3. Therefore, for firms run by single CEOs, the total effect of these coefficients is effectively zero, implying that single managers are much less affected by changes in idiosyncratic risk than married ones, which is consistent with the predictions of our model. While married CEOs strongly decrease investment in response to increases in idiosyncratic volatility, single ones do not alter their investment patterns. As in our previous tests, single managers are much less averse to idiosyncratic risk.

\subsection{Discussion}

Our results support the hypothesis that single CEOs assume more idiosyncratic risk than married ones. This is consistent with our model of CEO status-seeking that is motivated by the desire to find a suitable marriage partner and the resulting competition in the marriage market.

Of course, it is possible that single managers exhibit different risk-taking behavior from married managers even absent status concerns. People who are single at a given age may be inherently more risk-tolerant than those who are married by the same age. It would be possible to distinguish this scenario from our theory by exploiting changes in managers' marital status over time. Unfortunately, this would require a significant number of CEOs to experience marital status changes during their tenure, and for us to be able to document such a transition. Moreover, we would need to have precise dates of these marital transitions, which are difficult to obtain. ${ }^{18}$ Thus, we cannot convincingly distinguish our hypothesis from the alternative one that single and married CEOs are simply different using within-manager variation. Instead, in order to rule out the hypothesis of innate heterogeneity, we employ an instrumental variables approach described in the following section.

Another possibility is that marriage changes the utility of wealth by introducing spousal preferences into the CEO's objective function. For example, a CEO who has to support a spouse and children may have a higher required level of consumption expenditure and therefore income. This would make married CEOs effectively more risk-averse than single ones for reasons that have nothing to do with status. However, it seems likely that most, if

\footnotetext{
${ }^{18}$ We are able to find 76 CEOs in our sample who became married during their tenure, but for many of those the marital status change occurred right after they became CEO or shortly before them stepping down (thus not allowing a proper comparison of managerial decisions before and after marriage).
} 
not all, CEOs are wealthy enough for such concerns to be of second-order importance. At the same time, the impact of status concerns should be particularly pronounced in the upper tail of the wealth distribution.

It is also worth pointing out that both the innate heterogeneity and intra-family preference aggregation theories, at least in their simplest forms, do not predict that single CEOs will assume more idiosyncratic (rather than systematic) risk. In contrast, status concerns imply that it is exactly idiosyncratic risk that is of interest to single CEOs, as it affects the probability of outperforming their peers. In unreported results, we find evidence of portfolio under-diversification at the household level using the 2001 Survey of Consumer Finances, where single individuals have a greater share of their wealth invested in an average individual stock than married couples, while there is less evidence of great risk taking as such. This result also suggests that the effect of marital status on risk attitudes is not simply driven by pure differences in risk aversion, either inherent or induced by life-cycle considerations (such as consumption commitments), and is more likely to be driven by relative wealth concerns due to competition in the marriage market.

\section{Instrumental Variables Approach: Divorce Costs}

\subsection{Community Property vs. Equitable Division}

While some of the variation in CEOs' marital status is likely driven by their luck in finding a suitable marriage partner, some variation is likely due to the perceived costs of getting married. In particular, a nontrivial fraction of marriages, including those of CEOs, end in divorce. Since divorce is costly, this possibility should have an effect on an individual's propensity to enter into a marriage in the first place. For a wealthy person, a major concern is the division of property upon dissolution of a marriage. In the U.S., the division of marital assets upon divorce is regulated at the state level. Consequently, we can exploit the variation in the divorce laws across states of CEOs' residences, as it is plausibly exogenous both to the match between a firm and a CEO and to the firms' investment policies.

The most salient aspect of heterogeneity in the laws guiding the division of marital property is the distinction between community property and equitable division. The former man- 
dates equal division of all assets acquired during marriage between the two spouses upon divorce, whereas the latter follows the common law practice allowing the division to be determined by a judge based on a range of factors, including the relative contributions of the spouses. It is commonly understood that community property is more advantageous for the poorer spouse (see Voena (2011)). Since CEOs are typically substantially wealthier than their spouses, equal division of assets mandated by community property laws makes marriage costlier for them (insofar as there is a positive probability of its dissolution).

There are nine states in the U.S. that have adopted the community property system: Arizona, California, Idaho, Louisiana, Nevada, New Mexico, Texas, Washington, and Wisconsin. ${ }^{19}$ While community property legislation was adopted by these states at different points in time, it was in place in all of them throughout the period covered by our sample. Thus, there is little concern that political economy considerations could create an endogeneity problem, since it is highly unlikely that the passage of laws regulating divorce is systematically related to firms' investment opportunities and risk decades later. It is interesting to note that the use of the community property standard is not obviously related to (current) state characteristics. It is present in both rich and poor states, in large and small ones, as well as those whose populations' political preferences tend to be either predominantly liberal or predominantly conservative.

Although we do not directly observe the state of CEO residence, we can use the state in which the firm is headquartered as a reasonably good proxy for which type of jurisdiction is more relevant for the $\mathrm{CEO} .{ }^{20}$ While the number of community property jurisdictions is small, it includes some of the most populous states in the U.S., and thus represents approximately $36 \%$ of our sample of CEOs.

A potential issue is that prospective CEOs who are married may choose to reside in certain states because their divorce laws are more friendly to wealthy individuals. The market for CEOs in states where divorce is more costly would then have a relatively greater supply of potential CEOs who are single. If these CEOs are also more innately risk-tolerant on

\footnotetext{
${ }^{19}$ Puerto Rico is also a community property jurisdiction.

${ }^{20}$ Although a number of CEOs of companies headquartered in New York City reside in Connecticut or New Jersey, both of these are also equitable distribution states, and so there is no error due to misclassification for these CEOs.
} 
average, this could represent a problem for our instrument. However, given that the labor market for CEOs of public companies is likely nation-wide, this would require divorce laws to be a significant factor in determining where potential CEOs seek employment, which we believe is not plausible. What our instrument relies on is the assumption that a state's legal regime can influence a single CEO's decision whether to get married at a given point in time. More specifically, a CEO who is currently single and resides in a community property state is more likely to postpone marriage, holding all else equal.

Prenuptial agreements may limit the extent to which community property statutes impose a cost on wealthy individuals who marry less wealthy spouses. However, even among the wealthy their adoption is by no means universal. Moreover, enforcement of premarital agreement by the courts may not have been uniform over our sample period. ${ }^{21}$ To the extent that such agreements decrease the impact of state laws on the cost of divorce, and therefore on the probability of a single CEO getting married, this would only attenuate our first-stage estimates of the effect of community property states on CEO marital status, and consequently weaken the statistical power of the instrument in the second stage. Mismeasurement of the relevant jurisdiction would have a similar effect, weakening our results.

As a way of validating our instrumental variable approach externally to address some of these concerns, we analyze data from the entire U.S. population collected by the U.S. Census Bureau. The idea behind our instrument is that wealthier individuals are deterred from marriage (i.e., are more likely to be single, ceteris paribus), if they reside in a community property state. Thus, we test whether an additional interaction between measures of wealth/income and community property residence is positive, using the data from the 2000 U.S. Census $5 \%$ sample from the Integrated Public Use Microdata Series (IPUMS). Census does not collect data on wealth, therefore we can only use data on personal income of the head of household. Since current income is a noisy measure of lifetime income, especially for younger people, we also use data on occupation of the head of household in order to identify individuals who are likely to accumulate substantial wealth over time. In particular, we identify individuals with occupation codes "Lawyers" and "Surgeons and physicians." Finally, as an additional

\footnotetext{
${ }^{21} \mathrm{~A}$ recent example of a prenuptial agreement not upheld by the legal system in a community property jurisdiction is the high-profile divorce between Frank and Jamie McCourt (http://www.avvo.com/legalguides/ugc/judge-tosses-out-prenup-dodgers-ownership-still-undecided).
} 
measure that is closest to our focus on corporate CEOs, we separately identify individuals with occupation code "Chief executives." 22 We use two measures of single marital status: a narrow measure that includes only people reporting to have never been married, and a broad measure that includes those who never married as well as those who report their current marital status as either divorced or widowed. All of the regressions controlling for a quadratic in age to capture life-cycle effects.

Table 9 presents the results of these tests. The general regression specification is

Single $=\alpha+\beta \times C o m m+\gamma \times$ Income $+\delta \times A g e+\zeta \times \frac{A g e^{2}}{100}+\eta \times O c c+\chi \times$ Income $\times C o m m+\kappa \times \widetilde{O c c} \times C o m m$,

where Comm is the dummy variable equal to one if the household's state of residence is a community property state. Single is a dummy variable equal to one if the head of household has never been married (specification 1) or has never been married, is divorced, or is widowed (specifications 2-4). Income is in millions. Occ is a dummy variable for whether the head of household is either a lawyer or a surgeon/physician by occupation (specification 3) or a chief executive (specification 4). The interacted variables Income and $\widetilde{O c c}$ are demeaned using population weights. Consistent with our results using SCF data in Table 2, higher income individuals are less likely to be single, as are older individuals (albeit the effect of age is nonlinear).

In accordance with our hypothesis that higher-income individuals are less likely to be married if they reside in a community property jurisdiction, the interaction of income with the community property dummy is positive and highly statistically significant (with t-statistics around 10), regardless of which definition of single status is used. This occurs despite the fact that the effect of community property itself is actually negative (and significant, with t-statistics between 4 and 6). The effect of the community property regime on marriage rates in the general population can depend on a number of factors, such as the difference in income distribution or religious composition between the equitable distribution and community property states. However, this does not have an effect on the validity of our instrument. What matters is whether community property standard has a differential impact on the decisions

\footnotetext{
${ }^{22}$ This category is likely to include CEOs of privately held firms as well as, potentially, heads of nonprofit organizations. The number of public-company CEOs in this sample is likely to be small, given the small number of publicly listed companies relative to the total number of firms in the U.S.
} 
of wealthy individuals, and whether it makes it less likely for such individuals to get married.

Similarly to the results above, the interaction of a dummy for high-income occupations (doctors and lawyers) with the community property dummy is also positive and statistically significant (specification 3). The interaction of a CEO dummy with the community property dummy is also positive but not quite statistically significant, likely due to the fact that many individuals reporting "Chief executive" as their occupation are not actually sufficiently wealthy to be concerned about property division in divorce. We conclude that the effect of residing in a community property state on marital status is concentrated among the wealthier individuals, which validates the use of community property jurisdiction as a useful instrument for CEO single status, as well as alleviates concerns that this variable might be exclusively capturing unobserved heterogeneity across states.

The fact that residing in a community property state reduces the incentive for a wealthy person to get married by increasing the cost of potential divorce in no way suggests that the marriage market competition motive becomes inoperative. It merely implies that, holding all else equal, such a person will wait for a higher-quality match compared to a person residing in an equitable distribution jurisdiction. Therefore, at a given age and level of wealth, a community-property CEO is more likely to be single and, consequently, more willing to take on idiosyncratic risk in the hope of achieving high status.

\subsection{Instrumental Variable Results}

In the first stage, we regress the (potentially) endogenous variable Single on the instrumental variable, Community, which equals one if the firm is headquartered in one of the community property states and zero otherwise, as well as all of the control variables that we use. Our specification is as follows:

$$
\text { Single }=\alpha+\beta \times \text { Community }+\gamma \times X+\delta \times Y \text {, }
$$

where $X$ is a set of firm characteristics and $Y$ is a set of CEO characteristics. We also include industry and year fixed effects, which we do not tabulate.

Table 10 reports the estimated coefficients. In accordance with our hypothesis, Community 
has a highly significant effect on the probability of a CEO being single, controlling for all of the firm and CEO characteristics (including, in particular, CEO age and wealth, which both have predictably negative effects). Thus, variation in divorce laws represents a useful instrument for CEO marital status, and in fact a rather strong one, as suggested by t-statistics between 3.25 and 4.41 (calculated using robust standard errors clustered at state level). A CEO residing in a community property state is $4.9 \%$ more likely to be single relative to the unconditional probability of $16.2 \%$.

We then repeat the regressions for return volatility and for firm investment (given by Eq. (9)) using a two-stage least squares approach, where we substitute the fitted value from the first stage regression described above, SinglePred, for the endogenous variable Single. We report the results for our two main dependent variables: idiosyncratic stock return volatility and total firm investment.

Table 11 presents the second stage regression results for idiosyncratic volatility of firms' stock returns. The effect of the instrumented variable, SinglePred, is always strongly significant, regardless of specification, with t-statistics of 2.5 and above. Table 12 reports the second stage results for total investment, following the same specifications as in Table 5 . Again, the effect of the instrumented variable, SinglePred, is strong and statistically significant, with t-statistics between 1.88 and 2.99. In both cases, the inclusion of controls does not have much effect on the coefficient, except when all of the firm-level controls are dropped.

Overall, these results confirm the effect of marital status on firm risk-taking that is consistent with our model. The instrumental variable approach helps rule out innate heterogeneity among CEOs that is correlated with marital status as an explanation of our results. It also potentially strengthens our results by reducing the effect of measurement error that arises from our classification of CEOs into "single" and "married."

\subsection{State-level Variation}

One potential source of concern regarding our instrumental variable approach is the possibility that our instrument is systematically correlated with variation in firm investment opportunities across states. Most of the firms in our sample are fairly large companies operating at the national level, so that the economic activity in the state where their headquarters are 
located is unlikely to drive their investment opportunities. Nevertheless, as we do not have data on the geographic composition of firms' investment, we cannot rule out this possibility directly. Instead, we attempt to control for state-level variation in investment opportunities using state-level macroeconomic variables. ${ }^{23}$

We use the following variables to capture state-level economic activity: the annual growth rate in nonfarm payroll employment (Payroll) and the in-state Coincident Economic Activity Index constructed by the Federal Reserve Bank of Philadelphia $(C E A I)$, as well as the logarithm of real per capital income (LogIncomeState). Column (6) of Table 10 shows that adding these variables as controls in the first-stage regression does not have an effect, with none of the three coefficients being significant.

Column (6) in Tables 12 and 11 present the second-stage results for investment and idiosyncratic volatility, respectively, using the full set of controls, including the state-level ones. Our results are not altered by the inclusion of these controls. The only statistically significant state-level coefficient is that of LogIncomeState on investment, indicating that firms headquartered in states with higher per capita income on average invest more. At the same time, the effect of the state-level economic activity index, while not statistically significant, is negative. Overall, we conclude that our instrumental variable results are not likely to be due to differences in economic conditions across states.

\section{Conclusion}

There is substantial evidence in economics that interpersonal comparisons are important for individual subjective well-being (e.g., Luttmer (2005), Dynan and Ravina (2007)) and that such comparisons affect consumption choices (Charles, Hurst, and Roussanov (2009)). Less is known empirically about the impact of relative wealth concerns on attitudes towards risk. In this paper, we consider the implications of models in which status concerns arise endogenously as a result of competition in markets where allocations are not mediated by prices, such as the marriage market. In our model, complementarity between wealth and spouse quality induces single individuals to take on (idiosyncratic) risk in hopes of securing a

\footnotetext{
${ }^{23}$ The OLS results reported in Section 3 are robust to the inclusion of state fixed effects. Clearly, we cannot include these in the IV estimation due to the cross-sectional nature of our instrument.
} 
desirable mate. In particular, the model predicts that single individuals take more risk than married ones.

We use risk-taking by corporate CEOs as a setting for testing the model's predictions. CEOs represent the upper tail of the wealth distribution (Kaplan and Rauh (2010)), where status concerns are likely to be most acute. Moreover, their management decisions have significant economic impact. We find that single CEOs invest more aggressively (in capital expenditures, R\&D, advertising, and acquisitions) and that their companies exhibit higher stock return volatility (controlling for a variety of personal and firm characteristics). These effects are not only statistically significant, but also economically important. Our results are strengthened when we adopt an instrumental variable approach, based on variation in divorce laws across U.S. states. This variation is likely exogenous to firm investment and return volatility, but has a strong effect on the probability of a CEO being married, holding all else equal, and consequently on the measures of firm risk-taking.

In sum, our evidence supports the view that status concerns are important for financial decisions, and lead individuals to assume more risk. These findings have potentially rich implications in both corporate finance and asset pricing. In corporate finance, status concerns may help mitigate the potential underinvestment in risky projects and inefficiently high correlation with common shocks that are the consequences of risk aversion and moral hazard (since common shocks are more easily observable and can also be hedged by agents - Holmstrom (1982), Acharya and Bisin (2009)). This mitigating effect of status may play a significant role in various models of $\mathrm{CEO}$ compensation and, more generally, corporate governance. It may also help explain the mixed evidence in support of the hypothesis by Shleifer and Vishny (1986) that concentrated ownership leads to inefficient over-diversification of tightlyheld firms (e.g., Anderson and Reeb (2003) find the opposite result for family-controlled firms). In asset pricing, it may help reconcile the high investor risk aversion implied by the large risk premia on publicly traded assets with evidence of poor diversification of individual households' portfolios as well as with large amounts of idiosyncratic risk taken on by entrepreneurs. 


\section{References}

Abel, Andrew B., 1990, Asset prices under habit formation and catching up with the Joneses, American Economic Review 80, 38-42.

Acharya, Viral V., and Alberto Bisin, 2009, Managerial hedging, equity ownership, and firm value, RAND Journal of Economics 40, 47-77.

Adams, Renée B., Heitor Almeida, and Daniel Ferreira, 2005, Powerful CEOs and their impact on corporate performance, Review of Financial Studies 18, 1403-1432.

Anderson, Donald, and David Reeb, 2003, Founding-family ownership, corporate diversification, and firm leverage, Journal of Law and Economics 46, 653-684.

Baker, Michael D., and Jon K. Maner, 2008, Risk-taking as a situationally sensitive male mating strategy, Evolution and Human Behavior 29, 391-395.

Barber, Brad, and Terrance Odean, 2000, Boys will be boys: Gender, overconfidence, and common stock investment, Quarterly Journal of Economics 116, 261-292.

Becker, Gary S, 1973, A theory of marriage: Part I, Journal of Political Economy 81, 813-46.

Becker, Gary S., Kevin M. Murphy, and Ivan Werning, 2005, The equilibrium distribution of income and the market for status, Journal of Political Economy 113, 231-248.

Ben-David, Itzhak, John R. Graham, and Campbell R. Harvey, 2007, Managerial overconfidence and corporate policies, Working Paper 13711 National Bureau of Economic Research.

Benmelech, Efraim, and Carola Frydman, 2012, Military CEOs, Working Paper.

Bennedsen, Morten, Kasper Meisner Nielsen, Francisco Perez-Gonzalez, and Daniel Wolfenzon, 2007, Inside the family firm: The role of families in succession decisions and performance, Quarterly Journal of Economics 122, 647-691.

Bennedsen, Morten, Francisco Perez-Gonzalez, and Daniel Wolfenzon, 2006, Do CEOs Matter?, working paper. 
Bertrand, Marianne, and Antoinette Schoar, 2003, Managing with style: The effect of managers on firm policies, Quarterly Journal of Economics 118, 1169-1208.

Burnham, T.C, J.Flynn Chapman, P.B Gray, M.H McIntyre, S.F Lipson, and P.T Ellison, 2003, Men in committed, romantic relationships have lower testosterone, Hormones and Behavior 44, $119-122$.

Burnham, Terence C, 2007, High-testosterone men reject low ultimatum game offers., Proc Biol Sci 274, 2327-30.

Charles, Kerwin Kofi, Erik Hurst, and Alexandra Killewald, 2011, Marital sorting and parental wealth, NBER Working Paper 16748 National Bureau of Economic Research, Inc.

Charles, Kerwin Kofi, Erik Hurst, and Nikolai Roussanov, 2009, Conspicuous consumption and race, Quarterly Journal of Economics 124, 425-467.

Charles, Kerwin Kofi, and Ming Ching Luoh, 2010, Male incarceration, the marriage market, and female outcomes, Review of Economics and Statistics 92, 614-627.

Chiappori, Pierre-Andr, Sonia Oreffice, and Climent Quintana-Domeque, 2012, Fatter attraction: Anthropometric and socioeconomic matching on the marriage market, Journal of Political Economy 120, pp. 659-695.

Cole, Harold, George Mailath, and Andrew Postlewaite, 1992, Social norms, savings behavior and growth, Journal of Political Economy 100, 1092-1126.

— , 2001, Investment and concern for relative position, Review of Economic Design 6, $241-261$.

DeMarzo, Peter, Ron Kaniel, and Ilan Kremer, 2004, Diversification as a public good: Community effects in portfolio choice, Journal of Finance 59, 1677-1715.

Du, Qingyuan, and Shang-Jin Wei, 2010, A Sexually Unbalanced Model of Current Account Imbalances, NBER working paper. 
— , 2011, Sex Ratios and Exchange Rates, NBER working paper.

Dynan, Karen E., and Enrichetta Ravina, 2007, Increasing income inequality, external habits, and self-reported happiness, American Economic Review Papers and Proceedings 97, 226231.

Gale, D., and L. S. Shapley, 1962, College admissions and the stability of marriage, The American Mathematical Monthly 69, pp. 9-15.

Gervais, Simon, and Itay Goldstein, 2007, The positive effects of biased self-perceptions in firms, Review of Finance 11, 453-496.

Gervais, Simon, J. B. Heaton, and Terrance Odean, 2011, Overconfidence, compensation contracts, and capital budgeting, Journal of Finance 66, 1735-1777.

Goel, Anand M., and Anjan V. Thakor, 2008, Overconfidence, CEO selection, and corporate governance, Journal of Finance 63, 2737-2784.

Gollier, Christian, 2004, Misery loves company: Equilibrium portfolios with heterogeneous consumption externalities, International Economic Review 45, 1169-1192.

Graham, John R., Campbell R. Harvey, and Manju Puri, 2011, Managerial attitudes and corporate actions, Duke University Working Paper.

Gregory, Nathaniel, 1980, Relative wealth and risk taking: a short note on the FriedmanSavage utility function., Journal of Political Economy 88, 12261230.

Griskevicius, Vladas, Jill M. Sundie, Geoffrey F. Miller, Joshua M. Tybur, Robert B. Cialdini, and Douglas T. Kenrick, 2007, Blatant benevolence and conspicuous consumption: When romantic motives elicit costly displays, Journal of Personality and Social Psychology pp. $85-102$.

Guay, Wayne, 1999, The sensitivity of CEO wealth to equity risk: an analysis of the magnitude and determinants., Journal of Financial Economics 53, 4371.

Guiso, Luigi, and Aldo Rustichini, 2011, Understanding the size and profitability of firms: The role of a biological factor, Discussion paper. 
Hirshleifer, David, Angie Low, and Siew Hong Teoh, 2012, Are overconfident CEOs better innovators?, Journal of Finance 67, 1457-1498.

Holmstrom, Bengt, 1982, Moral hazard in teams, Bell Journal of Economics 13, 324-340.

Hopcroft, R, 2006, Sex, status, and reproductive success in the contemporary United States, Evolution and Human Behavior 27, 104-120.

Kaplan, Steven N., Mark M. Klebanov, and Morten Sorensen, 2008, Which CEO Characteristics and Abilities Matter?, Journal of Finance, forthcoming.

Kaplan, Steven N., and Joshua Rauh, 2010, Wall Street and Main Street: What Contributes to the Rise in the Highest Incomes?, Review of Financial Studies 23, 1004-1050.

Kennickell, Arthur, and Julia Lane, 2006, Measuring the impact of data protection techniques on data utility: Evidence from the survey of consumer finances, in Josep Domingo-Ferrer, and Luisa Franconi, ed.: Privacy in Statistical Databases, vol. 4302 of Lecture Notes in Computer Science . pp. 291-303 (Springer Berlin / Heidelberg).

Levi, Maurice, Kai Li, and Feng Zhang, 2010, Deal or No Deal: Hormones and the Mergers and Acquisitions Game, Management Science 56, 1462-1483.

Love, David A., 2010, The Effects of Marital Status and Children on Savings and Portfolio Choice, Review of Financial Studies 23, 385-432.

Luttmer, Erzo, F. P., 2005, Neighbors as negatives: Relative earnings and well-being, Quarterly Journal of Economics 120, 963-1002.

Malmendier, Ulrike, and Geoffrey Tate, 2005, CEO overconfidence and corporate investment, Journal of Finance 60, 2661-2700.

— 2009, Superstar CEOs, Quarterly Journal of Economics 124, 1593-1638.

and Jon Yan, 2011, Overconfidence and early-life experiences: The effect of managerial traits on corporate financial policies, The Journal of Finance 66, 1687-1733. 
Morse, Adair, Vikram Nanda, and Amit Seru, 2011, Are incentive contracts rigged by powerful ceos?, Journal of Finance 66, 1779-1821.

Nettle, D, and T V Pollet, 2008, Natural selection on male wealth in humans, The American Naturalist 172, 658-666.

Panousi, Vasia, and Dimitris Papanikolaou, 2012, Investment, idiosyncratic risk, and ownership, Journal of Finance 67, 1113-1148.

Pollet, Thomas V., and Daniel Nettle, 2009, Partner wealth predicts self-reported orgasm frequency in a sample of Chinese women, Evolution and Human Behavior 30, 146 - 151.

Postlewaite, Andrew, 1998, The social basis of interdependent preferences, European Economic Review 42, 779-800.

Robson, Arthur J., 1992, Status, the distribution of wealth, private and social attitudes to risk, Econometrica 60, 837-857.

Roth, Alvin E., and Marilda A. Oliveira Sotomayor, 1990, Two-Sided Matching: a Study in Game-Theoretic Modeling and Analysis (Cambridge University Press).

Roussanov, Nikolai, 2010a, Diversification and its discontents: Idiosyncratic and entrepreneurial risk in the quest for social status, Journal of Finance 65, 1755-1788.

— , 2010b, Internet appendix to "Diversification and its discontents: Idiosyncratic and entrepreneurial risk in the quest for social status", Journal of Finance 65, 1755-1788.

Sapienza, Paola, Luigi Zingales, and Dario Maestripieri, 2009, Gender differences in financial risk aversion and career choices are affected by testosterone, Proceedings of the National Academy of Sciences.

Schoar, Antoinette, and Luo Zuo, 2011, Shaped by booms and busts: How the economy impacts ceo careers and management style, Working Paper 17590 National Bureau of Economic Research.

Shemesh, Joshua, 2010, CEO Social Status and Risk Taking, Working Paper. 
Shleifer, Andrei, and Robert W Vishny, 1986, Large shareholders and corporate control, Journal of Political Economy 94, 461-88.

Voena, Alessandra, 2011, Yours, mine and ours: Do divorce laws affect the intertemporal behavior of married couples?, Discussion Paper 10-022 Stanford Instititute for Economic Policy Research.

Wei, Shang-Jin, and Xiaobo Zhang, 2011a, The competitive saving motive: Evidence from rising sex ratios and savings rates in China, Journal of Political Economy 119, pp. 511-564.

— , 2011b, Sex Ratios, Entrepreneurship, and Economic Growth in the People's Republic of China, NBER working paper.

Wilson, Margo, and Martin Daly, 2004, Do pretty women inspire men to discount the future?, Proceedings: Biological Sciences 271, pp. S177-S179. 
Table 1: Summary Statistics

Panel A. Risk-taking measures

\begin{tabular}{lrrrrrrr}
\hline \hline & Investment & CapEx & R\&D & Advertising & Net Acq. & Vol. & Id. vol. \\
\hline Mean & & \multicolumn{7}{c}{ Married CEOs } & & & \\
Median & 0.90 & 0.27 & 0.25 & 0.08 & 0.24 & 0.37 & 0.34 \\
1st. Perct. & 0.36 & 0.19 & 0.00 & 0.00 & 0.00 & 0.31 & 0.28 \\
99th Perct. & -0.02 & 0.01 & 0.00 & 0.00 & -0.31 & 0.00 & 0.09 \\
N & 11.25 & 1.69 & 4.50 & 1.63 & 6.31 & 3.72 & 1.12 \\
\hline & 21,876 & 21,876 & 21,876 & 21,876 & 21,876 & 20,433 & 20,418 \\
\hline Mean & & & & Single CEOs & & & 0.42 \\
Median & 1.52 & 0.32 & 0.58 & 0.12 & 0.38 & 0.45 & 0.34 \\
1st. Perct. & 0.48 & 0.22 & 0.00 & 0.00 & 0.00 & 0.37 & 0.11 \\
99th Perct. & 0.00 & 0.00 & 0.00 & 0.00 & -0.29 & 0.07 & 1.41 \\
N & 19.85 & 2.04 & 8.86 & 3.94 & 9.51 & 9.51 & 3,785 \\
\hline
\end{tabular}

Panel B. Control variables

\begin{tabular}{lrrrrrrrr}
\hline \multicolumn{1}{c}{ Panel B. Control variables } \\
\hline \hline & Assets & M/B & \multicolumn{1}{c}{ CF } & Leverage & Firm Age & CEO Age & Tenure & Wealth \\
\hline Mean & 12,517 & 1.94 & 0.54 & 0.36 & 25.6 & 55.0 & 5.1 & 166 \\
Median & 1,615 & 1.46 & 0.39 & 0.35 & 22.0 & 55.0 & 4.0 & 16 \\
1st. Perct. & 47 & 0.79 & -5.30 & 0.00 & 3.0 & 38.0 & 0.0 & 0 \\
99th Perct. & 208,335 & 8.85 & 8.38 & 1.27 & 57.0 & 77.0 & 24.0 & 1,853 \\
N & 21,856 & 21,876 & 21,876 & 21,876 & 21,876 & 20,885 & 21,876 & 16,531 \\
\hline & & & \multicolumn{7}{c}{ Married CEOs } \\
Mean & 2,076 & 2.14 & 0.31 & 0.30 & 18.5 & 52.6 & 4.5 & 36 \\
Median & 595 & 1.56 & 0.37 & 0.25 & 13.0 & 53.0 & 3.0 & 8 \\
1st. Perct. & 26 & 0.69 & -12.20 & 0.00 & 3.0 & 36.0 & 0.0 & 0 \\
99th Perct. & 24,563 & 10.82 & 17.42 & 1.57 & 57.0 & 70.0 & 22 & 360 \\
N & 4220 & 4,224 & 4,224 & 4,224 & 4,224 & 3,960 & 4,224 & 2,969 \\
\hline
\end{tabular}

Panel A reports the summary statistics for various measures of firm risk-taking. Investment (Investment) and its components (CapEx, R\&D, Advertising, and NetAcquisitions) are relative to PP\&E. Volatility is the (annualized) standard deviation of monthly stock returns over the previous year. Idiosyncratic volatility is the standard deviation of residuals from the regression of stock returns on the market return.

Panel B reports the summary statistics for our main control variables. Firm assets $(A)$ and CEO wealth (Wealth) are expressed in millions. Market-to-book ratio $(M / B)$ is the ratio of the market value of assets to their book value. Cash flow $(C F)$ equals earnings before extraordinary items plus depreciation \& amortization, scaled by net PP\&E. Book leverage (Leverage) equals the sum of long-term and current debt divided by the sum of long-term debt, current debt, and book equity. Firm age (Firm Age) is computed with respect to the first year it appears in COMPUSTAT (expressed in years, as are CEO age and tenure). 
Table 2: CEO Marital Status: A Diagnostic

\begin{tabular}{lccccc}
\hline \hline & 1 & 2 & 3 & 4 & 5 \\
\hline Intercept & 2.455 & 1.452 & 2.396 & 2.391 & 1.410 \\
& $(0.000)$ & $(0.000)$ & $(0.000)$ & $(0.000)$ & $(0.000)$ \\
Net Worth & -0.032 & & & -0.018 & \\
& $(0.000)$ & & & $(0.000)$ & \\
Largest Asset & & -0.018 & & & -0.011 \\
& & $(0.000)$ & & & $(0.001)$ \\
Income & & & -0.488 & -0.279 & -0.080 \\
Age & -0.130 & -0.121 & -0.125 & -0.126 & -0.118 \\
\multirow{2}{*}{ Age ${ }^{2} /$ 100 } & $(0.000)$ & $(0.000)$ & $(0.000)$ & $(0.000)$ & $(0.000)$ \\
& 0.125 & 0.113 & 0.119 & 0.121 & 0.111 \\
Pr(Single|MedianCEO) & $(0.000)$ & $(0.000)$ & $(0.000)$ & $(0.000)$ & $(0.000)$ \\
& 0.203 & 0.117 & 0.122 & 0.149 & 0.113 \\
& & & & & \\
\hline
\end{tabular}

This table presents the results of logit regressions of marital status on measures of wealth, income, and age:

$$
\operatorname{Pr}(\text { Single })=\Phi\left(\alpha+\beta \times \text { Wealth }+\gamma \times \text { Income }+\delta \times \text { Age }+\zeta \times \frac{A^{2} e^{2}}{100}\right),
$$

where $\Phi$ is the logistic c.d.f. Data is from the 2001 Survey of Consumer Finances. Specifications (1) and (4) use Net Worth as a measure of wealth in the SCF, while specifications (2) and (5) use the value of the single largest risky asset holding (Largest Asset) as a proxy for wealth. We also show the implied probability of a median CEO being single based on these estimates. The implied probabilities are computed based on the median CEO wealth of $\$ 13.8$ million (using CEO's holdings of company stock and options), median CEO income of $\$ 2.2$ million, and median CEO age of 55 years. 
Table 3: Regression Results for Total Stock Return Volatility

\begin{tabular}{|c|c|c|c|c|c|c|}
\hline & 1 & 2 & 3 & 4 & 5 & 6 \\
\hline$C F_{t}$ & $\begin{array}{c}-0.006 \\
(-6.430)\end{array}$ & $\begin{array}{c}-0.005 \\
(-5.694)\end{array}$ & $\begin{array}{c}-0.005 \\
(-5.753)\end{array}$ & $\begin{array}{c}-0.005 \\
(-5.781)\end{array}$ & $\begin{array}{c}-0.006 \\
(-6.810)\end{array}$ & \\
\hline$M_{t-1} / B_{t-1}$ & $\begin{array}{c}0.006 \\
(3.938)\end{array}$ & $\begin{array}{c}0.005 \\
(3.200)\end{array}$ & $\begin{array}{c}0.004 \\
(3.016)\end{array}$ & $\begin{array}{c}0.004 \\
(3.074)\end{array}$ & $\begin{array}{c}0.000 \\
(0.210)\end{array}$ & \\
\hline $\log A_{t-1}$ & $\begin{array}{c}-0.022 \\
(-10.978)\end{array}$ & $\begin{array}{c}-0.022 \\
(-10.546)\end{array}$ & $\begin{array}{c}-0.024 \\
(-9.768)\end{array}$ & $\begin{array}{c}-0.023 \\
(-9.892)\end{array}$ & $\begin{array}{c}-0.022 \\
(-9.120)\end{array}$ & \\
\hline Leverage $_{t}$ & $\begin{array}{c}0.077 \\
(8.708)\end{array}$ & $\begin{array}{c}0.071 \\
(7.975)\end{array}$ & $\begin{array}{c}0.072 \\
(7.977)\end{array}$ & $\begin{array}{c}0.072 \\
(8.002)\end{array}$ & $\begin{array}{c}0.097 \\
(10.130)\end{array}$ & \\
\hline Vol $_{t-1}$ & $\begin{array}{c}0.408 \\
(9.523)\end{array}$ & $\begin{array}{c}0.405 \\
(8.891)\end{array}$ & $\begin{array}{c}0.404 \\
(8.850)\end{array}$ & $\begin{array}{c}0.401 \\
(8.659)\end{array}$ & $\begin{array}{c}0.387 \\
(7.930)\end{array}$ & \\
\hline FirmAge & $\begin{array}{c}-0.001 \\
(-6.678)\end{array}$ & $\begin{array}{c}-0.001 \\
(-6.428)\end{array}$ & $\begin{array}{c}-0.001 \\
(-6.384)\end{array}$ & $\begin{array}{c}-0.001 \\
(-6.436)\end{array}$ & $\begin{array}{c}-0.001 \\
(-7.320)\end{array}$ & \\
\hline Single & $\begin{array}{c}0.012 \\
(2.640)\end{array}$ & $\begin{array}{c}0.008 \\
(1.761)\end{array}$ & $\begin{array}{c}0.009 \\
(2.054)\end{array}$ & $\begin{array}{c}0.011 \\
(2.303)\end{array}$ & $\begin{array}{c}0.012 \\
(2.320)\end{array}$ & $\begin{array}{c}0.067 \\
(7.827)\end{array}$ \\
\hline Age & & $\begin{array}{c}-0.001 \\
(-4.114)\end{array}$ & $\begin{array}{c}-0.001 \\
(-3.781)\end{array}$ & $\begin{array}{c}-0.001 \\
(-3.842)\end{array}$ & $\begin{array}{c}-0.001 \\
(-3.470)\end{array}$ & $\begin{array}{c}-0.004 \\
(-11.458)\end{array}$ \\
\hline Age $\times$ Single & & $\begin{array}{c}-0.001 \\
(-1.460)\end{array}$ & $\begin{array}{c}-0.001 \\
(-1.452)\end{array}$ & $\begin{array}{c}-0.001 \\
(-1.530)\end{array}$ & $\begin{array}{c}-0.001 \\
(-1.520)\end{array}$ & $\begin{array}{c}-0.002 \\
(-1.188)\end{array}$ \\
\hline Tenure & & $\begin{array}{c}-0.001 \\
(-1.877)\end{array}$ & $\begin{array}{c}-0.001 \\
(-1.992)\end{array}$ & $\begin{array}{c}-0.001 \\
(-2.300)\end{array}$ & $\begin{array}{c}-0.001 \\
(-2.340)\end{array}$ & $\begin{array}{c}-0.001 \\
(-1.021)\end{array}$ \\
\hline Tenure $\times$ Single & & $\begin{array}{c}0.001 \\
(0.693)\end{array}$ & $\begin{array}{c}0.000 \\
(0.610)\end{array}$ & $\begin{array}{c}0.001 \\
(0.843)\end{array}$ & $\begin{array}{c}0.002 \\
(1.800)\end{array}$ & $\begin{array}{c}-0.000 \\
(-0.198)\end{array}$ \\
\hline CEOProminence & & & $\begin{array}{c}0.003 \\
(3.115)\end{array}$ & $\begin{array}{c}0.003 \\
(3.152)\end{array}$ & $\begin{array}{c}0.003 \\
(2.750)\end{array}$ & $\begin{array}{c}-0.007 \\
(-4.556)\end{array}$ \\
\hline FirmProminence & & & $\begin{array}{c}-0.001 \\
(-0.962)\end{array}$ & $\begin{array}{c}-0.001 \\
(-0.972)\end{array}$ & $\begin{array}{c}-0.001 \\
(-1.190)\end{array}$ & \\
\hline Inst & & & & $\begin{array}{c}-0.034 \\
(-3.789)\end{array}$ & $\begin{array}{c}-0.045 \\
(-4.710)\end{array}$ & \\
\hline Inst $\times$ Single & & & & $\begin{array}{c}-0.061 \\
(-1.951) \\
\end{array}$ & $\begin{array}{c}-0.054 \\
(-1.610) \\
\end{array}$ & \\
\hline$R^{2}$ & 0.481 & 0.482 & 0.482 & 0.484 & 0.512 & 0.196 \\
\hline
\end{tabular}

The table reports coefficient estimates of the following OLS regression:

$$
\text { Vol }=\alpha+\beta \times \text { Single }+\gamma \times X+\delta \times Y+\zeta \times(\text { Single } \times \tilde{Y}),
$$

where $\mathrm{Vol}$ is the annualized standard deviation of monthly stock returns over the previous year, Single is a dummy variable equaling one if the CEO is unmarried and zero otherwise, $X$ is a set of firm characteristics, and $Y$ is a set of CEO characteristics (the specific variable definitions are given in Section 2), demeaned when used in interaction terms: $\tilde{Y}=Y-\hat{E} Y$. All specifications also include industry (based on the Fama-French 49-industry classification) and year fixed effects (unreported), with the exception of specification (5), which includes industry $\times$ year fixed effects. T-statistics are in parentheses, and are computed using robust standard errors clustered by firm. 
Table 4: Regression Results for Idiosyncratic Return Volatility

\begin{tabular}{|c|c|c|c|c|c|c|}
\hline & 1 & 2 & 3 & 4 & 5 & 6 \\
\hline$C F_{t}$ & $\begin{array}{c}-0.005 \\
(-5.488)\end{array}$ & $\begin{array}{c}-0.004 \\
(-4.816)\end{array}$ & $\begin{array}{c}-0.004 \\
(-4.885)\end{array}$ & $\begin{array}{c}-0.004 \\
(-4.858)\end{array}$ & $\begin{array}{c}-0.004 \\
(-4.200)\end{array}$ & \\
\hline$M_{t-1} / B_{t-1}$ & $\begin{array}{l}0.001 \\
(0.890)\end{array}$ & $\begin{array}{l}0.000 \\
(0.233)\end{array}$ & $\begin{array}{c}0.000 \\
(0.011)\end{array}$ & $\begin{array}{c}0.000 \\
(0.049)\end{array}$ & $\begin{array}{c}-0.002 \\
(-1.680)\end{array}$ & \\
\hline $\log A_{t-1}$ & $\begin{array}{c}-0.027 \\
(-12.689)\end{array}$ & $\begin{array}{c}-0.027 \\
(-12.330)\end{array}$ & $\begin{array}{c}-0.028 \\
(-11.506)\end{array}$ & $\begin{array}{c}-0.027 \\
(-11.719)\end{array}$ & $\begin{array}{c}-0.027 \\
(-11.850)\end{array}$ & \\
\hline Leverage $_{t}$ & $\begin{array}{c}0.082 \\
(9.644)\end{array}$ & $\begin{array}{c}0.078 \\
(8.988)\end{array}$ & $\begin{array}{c}0.078 \\
(9.010)\end{array}$ & $\begin{array}{c}0.079 \\
(9.104)\end{array}$ & $\begin{array}{c}0.085 \\
(9.690)\end{array}$ & \\
\hline$I d V o l_{t-1}$ & $\begin{array}{c}0.346 \\
(8.197)\end{array}$ & $\begin{array}{c}0.341 \\
(7.637)\end{array}$ & $\begin{array}{c}0.340 \\
(7.608)\end{array}$ & $\begin{array}{c}0.335 \\
(7.357)\end{array}$ & $\begin{array}{c}0.327 \\
(7.260)\end{array}$ & \\
\hline FirmAge & $\begin{array}{c}-0.001 \\
(-6.853)\end{array}$ & $\begin{array}{c}-0.001 \\
(-6.627)\end{array}$ & $\begin{array}{c}-0.001 \\
(-6.572)\end{array}$ & $\begin{array}{c}-0.001 \\
(-6.702)\end{array}$ & $\begin{array}{c}-0.001 \\
(-7.200)\end{array}$ & \\
\hline Single & $\begin{array}{c}0.012 \\
(2.667)\end{array}$ & $\begin{array}{c}0.008 \\
(1.927)\end{array}$ & $\begin{array}{c}0.010 \\
(2.236)\end{array}$ & $\begin{array}{c}0.012 \\
(2.551)\end{array}$ & $\begin{array}{c}0.012 \\
(2.520)\end{array}$ & $\begin{array}{c}0.063 \\
(8.085)\end{array}$ \\
\hline Age & & $\begin{array}{c}-0.001 \\
(-3.927)\end{array}$ & $\begin{array}{c}-0.001 \\
(-3.551)\end{array}$ & $\begin{array}{c}-0.001 \\
(-3.654)\end{array}$ & $\begin{array}{c}-0.001 \\
(-3.710)\end{array}$ & $\begin{array}{c}-0.004 \\
(-11.370)\end{array}$ \\
\hline Age $\times$ Single & & $\begin{array}{c}-0.001 \\
(-1.278)\end{array}$ & $\begin{array}{c}-0.001 \\
(-1.271)\end{array}$ & $\begin{array}{c}-0.001 \\
(-1.371)\end{array}$ & $\begin{array}{c}-0.001 \\
(-1.310)\end{array}$ & $\begin{array}{c}-0.001 \\
(-0.960)\end{array}$ \\
\hline Tenure & & $\begin{array}{c}-0.000 \\
(-1.609)\end{array}$ & $\begin{array}{c}-0.000 \\
(-1.733)\end{array}$ & $\begin{array}{c}-0.001 \\
(-2.169)\end{array}$ & $\begin{array}{c}-0.001 \\
(-2.070)\end{array}$ & $\begin{array}{c}-0.000 \\
(-0.819)\end{array}$ \\
\hline Tenure $\times$ Single & & $\begin{array}{c}0.000 \\
(0.131)\end{array}$ & $\begin{array}{c}0.000 \\
(0.038)\end{array}$ & $\begin{array}{c}0.000 \\
(0.352)\end{array}$ & $\begin{array}{c}0.000 \\
(0.230)\end{array}$ & $\begin{array}{c}-0.001 \\
(-0.464)\end{array}$ \\
\hline CEOProminence & & & $\begin{array}{c}0.003 \\
(3.298)\end{array}$ & $\begin{array}{c}0.003 \\
(3.365)\end{array}$ & $\begin{array}{c}0.003 \\
(2.890)\end{array}$ & $\begin{array}{c}-0.008 \\
(-6.177)\end{array}$ \\
\hline FirmProminence & & & $\begin{array}{c}-0.001 \\
(-0.913)\end{array}$ & $\begin{array}{c}-0.001 \\
(-0.934)\end{array}$ & $\begin{array}{c}-0.001 \\
(-0.640)\end{array}$ & \\
\hline Inst & & & & $\begin{array}{c}-0.047 \\
(-5.269)\end{array}$ & $\begin{array}{c}-0.050 \\
(-5.590)\end{array}$ & \\
\hline Inst $\times$ Single & & & & $\begin{array}{c}-0.076 \\
(-2.253)\end{array}$ & $\begin{array}{c}-0.064 \\
(-1.930)\end{array}$ & \\
\hline$R^{2}$ & 0.443 & 0.442 & 0.443 & 0.445 & 0.482 & 0.189 \\
\hline
\end{tabular}

The table reports coefficient estimates of the following OLS regression:

$$
I d V o l=\alpha+\beta \times \text { Single }+\gamma \times X+\delta \times Y+\zeta \times(\text { Single } \times \tilde{Y}),
$$

where $I d V o l$ is the annualized standard deviation of residuals from the regression of firm monthly stock returns on the market return, Single is a dummy variable equaling one if the CEO is unmarried and zero otherwise, $X$ is a set of firm characteristics, and $Y$ is a set of CEO characteristics (the specific variable definitions are given in Section 2), demeaned when used in interaction terms: $\tilde{Y}=Y-\hat{E} Y$. All specifications also include industry (based on the Fama-French 49-industry classification) and year fixed effects (unreported), with the exception of specification (5), which includes industry $\times$ year fixed effects. T-statistics are in parentheses, and are computed using robust standard errors clustered by firm. 
Table 5: Regression Results for Total Investment

\begin{tabular}{|c|c|c|c|c|c|c|}
\hline & 1 & 2 & 3 & 4 & 5 & 6 \\
\hline$C F_{t}$ & $\begin{array}{c}0.091 \\
(5.551)\end{array}$ & $\begin{array}{l}0.096 \\
(5.941)\end{array}$ & $\begin{array}{c}0.095 \\
(5.882)\end{array}$ & $\begin{array}{c}0.095 \\
(5.878)\end{array}$ & $\begin{array}{c}0.094 \\
(5.710)\end{array}$ & \\
\hline$M_{t-1} / B_{t-1}$ & $\begin{array}{c}0.118 \\
(7.894)\end{array}$ & $\begin{array}{c}0.114 \\
(7.676)\end{array}$ & $\begin{array}{c}0.108 \\
(7.363)\end{array}$ & $\begin{array}{c}0.108 \\
(7.349)\end{array}$ & $\begin{array}{c}0.109 \\
(7.340)\end{array}$ & \\
\hline $\log A_{t-1}$ & $\begin{array}{c}-0.128 \\
(-11.844)\end{array}$ & $\begin{array}{c}-0.131 \\
(-11.847)\end{array}$ & $\begin{array}{c}-0.151 \\
(-11.335)\end{array}$ & $\begin{array}{c}-0.154 \\
(-11.745)\end{array}$ & $\begin{array}{c}-0.145 \\
(-11.170)\end{array}$ & \\
\hline Leverage $_{t}$ & $\begin{array}{c}0.195 \\
(3.525)\end{array}$ & $\begin{array}{c}0.188 \\
(3.328)\end{array}$ & $\begin{array}{c}0.198 \\
(3.498)\end{array}$ & $\begin{array}{c}0.198 \\
(3.506)\end{array}$ & $\begin{array}{c}0.205 \\
(3.660)\end{array}$ & \\
\hline Investment $_{t-1}$ & $\begin{array}{c}0.484 \\
(18.104)\end{array}$ & $\begin{array}{c}0.476 \\
(19.099)\end{array}$ & $\begin{array}{c}0.475 \\
(19.043)\end{array}$ & $\begin{array}{c}0.475 \\
(18.980)\end{array}$ & $\begin{array}{c}0.477 \\
(18.940)\end{array}$ & \\
\hline FirmAge & $\begin{array}{c}-0.002 \\
(-3.071)\end{array}$ & $\begin{array}{c}-0.002 \\
(-2.418)\end{array}$ & $\begin{array}{c}-0.002 \\
(-2.350)\end{array}$ & $\begin{array}{c}-0.002 \\
(-2.273)\end{array}$ & $\begin{array}{c}-0.002 \\
(-2.720)\end{array}$ & \\
\hline Single & $\begin{array}{c}0.093 \\
(2.349)\end{array}$ & $\begin{array}{c}0.069 \\
(1.712)\end{array}$ & $\begin{array}{c}0.090 \\
(2.249)\end{array}$ & $\begin{array}{c}0.087 \\
(2.181)\end{array}$ & $\begin{array}{c}0.105 \\
(2.650)\end{array}$ & $\begin{array}{c}0.453 \\
(5.234)\end{array}$ \\
\hline Age & & $\begin{array}{c}-0.004 \\
(-2.782)\end{array}$ & $\begin{array}{c}-0.003 \\
(-2.114)\end{array}$ & $\begin{array}{c}-0.003 \\
(-2.072)\end{array}$ & $\begin{array}{c}-0.004 \\
(-2.700)\end{array}$ & $\begin{array}{l}-0.029 \\
(-9.768)\end{array}$ \\
\hline Age $\times$ Single & & $\begin{array}{c}-0.019 \\
(-2.613)\end{array}$ & $\begin{array}{c}-0.019 \\
(-2.631)\end{array}$ & $\begin{array}{c}-0.019 \\
(-2.638)\end{array}$ & $\begin{array}{c}-0.017 \\
(-2.440)\end{array}$ & $\begin{array}{l}-0.042 \\
(-2.928)\end{array}$ \\
\hline Tenure & & $\begin{array}{c}-0.009 \\
(-3.727)\end{array}$ & $\begin{array}{l}-0.009 \\
(-3.920)\end{array}$ & $\begin{array}{c}-0.009 \\
(-3.875)\end{array}$ & $\begin{array}{l}-0.007 \\
(-3.410)\end{array}$ & $\begin{array}{l}-0.007 \\
(-1.262)\end{array}$ \\
\hline Tenure $\times$ Single & & $\begin{array}{c}0.017 \\
(1.440)\end{array}$ & $\begin{array}{c}0.016 \\
(1.372)\end{array}$ & $\begin{array}{c}0.016 \\
(1.389)\end{array}$ & $\begin{array}{c}0.015 \\
(1.320)\end{array}$ & $\begin{array}{c}0.039 \\
(1.474)\end{array}$ \\
\hline CEOProminence & & & $\begin{array}{c}0.035 \\
(3.832)\end{array}$ & $\begin{array}{c}0.035 \\
(3.842)\end{array}$ & $\begin{array}{c}0.032 \\
(3.550)\end{array}$ & $\begin{array}{l}-0.002 \\
(-0.186)\end{array}$ \\
\hline FirmProminence & & & $\begin{array}{c}0.004 \\
(0.405)\end{array}$ & $\begin{array}{c}0.004 \\
(0.416)\end{array}$ & $\begin{array}{c}0.004 \\
(0.350)\end{array}$ & \\
\hline Inst & & & & $\begin{array}{c}0.133 \\
(1.849)\end{array}$ & $\begin{array}{c}0.121 \\
(1.680)\end{array}$ & \\
\hline Inst $\times$ Single & & & & $\begin{array}{c}0.022 \\
(0.103)\end{array}$ & $\begin{array}{c}0.019 \\
(0.090)\end{array}$ & \\
\hline$R^{2}$ & 0.445 & 0.444 & 0.445 & 0.445 & 0.463 & 0.043 \\
\hline
\end{tabular}

The table reports coefficient estimates of the following OLS regression:

$$
\text { Investment }=\alpha+\beta \times \text { Single }+\gamma \times X+\delta \times Y+\zeta \times(\text { Single } \times \tilde{Y}),
$$

where Investment is capital expenditures plus acquisitions minus asset sales plus R\&D expenditure plus advertising expenditure (scaled by net property, plant \& equipment), Single is a dummy variable equaling one if the CEO is unmarried and zero otherwise, $X$ is a set of firm characteristics, and $Y$ is a set of CEO characteristics (the specific variable definitions are given in Section 2), demeaned when used in interaction terms: $\tilde{Y}=Y-\hat{E} Y$. All specifications also include industry (based on the Fama-French 49-industry classification) and year fixed effects (unreported), with the exception of specification (5), which includes industry $\times$ year fixed effects. T-statistics are in parentheses, and are computed using robust standard errors clustered by firm. 
Table 6: Regression Results for Net Acquisitions

\begin{tabular}{|c|c|c|c|c|c|c|}
\hline & 1 & 2 & 3 & 4 & 5 & 6 \\
\hline \multirow[t]{2}{*}{$C F$} & 0.069 & 0.070 & 0.070 & 0.069 & 0.071 & \\
\hline & $(10.620)$ & $(10.215)$ & (10.194) & $(10.145)$ & $(10.130)$ & \\
\hline \multirow[t]{2}{*}{$M_{t-1} / B_{t-1}$} & 0.015 & 0.016 & 0.015 & 0.015 & 0.016 & \\
\hline & $(2.370)$ & $(2.344)$ & $(2.167)$ & $(2.177)$ & $(2.280)$ & \\
\hline \multirow[t]{2}{*}{$\log A_{t-1}$} & -0.046 & -0.047 & -0.050 & -0.053 & -0.049 & \\
\hline & $(-8.394)$ & $(-8.566)$ & $(-8.133)$ & $(-8.570)$ & $(-7.820)$ & \\
\hline \multirow[t]{2}{*}{ Leverage } & 0.242 & 0.250 & 0.251 & 0.252 & 0.266 & \\
\hline & $(7.438)$ & $(7.409)$ & $(7.405)$ & $(7.424)$ & $(7.760)$ & \\
\hline \multirow[t]{2}{*}{ NetAcq $q_{t-1}$} & 0.239 & 0.237 & 0.237 & 0.236 & 0.230 & \\
\hline & (13.332) & (13.135) & (13.147) & $(13.069)$ & (13.130) & \\
\hline \multirow[t]{2}{*}{ FirmAge } & -0.001 & -0.001 & -0.001 & -0.001 & -0.001 & \\
\hline & $(-3.109)$ & $(-2.718)$ & $(-2.683)$ & $(-2.530)$ & $(-2.790)$ & \\
\hline \multirow[t]{2}{*}{ Single } & 0.035 & 0.035 & 0.039 & 0.038 & 0.048 & 0.095 \\
\hline & $(1.415)$ & $(1.347)$ & $(1.482)$ & $(1.452)$ & $(1.900)$ & $(2.587)$ \\
\hline \multirow[t]{2}{*}{ Age } & & -0.001 & -0.000 & -0.000 & -0.001 & -0.005 \\
\hline & & $(-0.621)$ & $(-0.414)$ & $(-0.312)$ & $(-0.920)$ & $(-3.741)$ \\
\hline \multirow[t]{2}{*}{ Age $\times$ Single } & & -0.007 & -0.006 & -0.007 & -0.006 & -0.012 \\
\hline & & $(-1.753)$ & $(-1.749)$ & $(-1.762)$ & $(-1.600)$ & $(-2.276)$ \\
\hline \multirow[t]{2}{*}{ Tenure } & & -0.004 & -0.004 & -0.004 & -0.003 & -0.003 \\
\hline & & $(-2.107)$ & $(-2.162)$ & $(-2.160)$ & $(-1.640)$ & $(-1.257)$ \\
\hline \multirow[t]{2}{*}{ Tenure $\times$ Single } & & 0.013 & 0.013 & 0.013 & 0.013 & 0.021 \\
\hline & & $(1.655)$ & $(1.640)$ & $(1.653)$ & $(1.610)$ & $(1.844)$ \\
\hline \multirow[t]{2}{*}{ CEOProminence } & & & 0.008 & 0.008 & 0.006 & -0.014 \\
\hline & & & $(1.504)$ & $(1.519)$ & $(1.230)$ & $(-2.587)$ \\
\hline \multirow[t]{2}{*}{ FirmProminence } & & & -0.001 & -0.001 & -0.002 & \\
\hline & & & $(-0.217)$ & $(-0.178)$ & $(-0.320)$ & \\
\hline \multirow[t]{2}{*}{ Inst } & & & & 0.182 & 0.167 & \\
\hline & & & & $(5.048)$ & $(4.520)$ & \\
\hline \multirow[t]{2}{*}{ Inst $\times$ Single } & & & & -0.063 & -0.080 & \\
\hline & & & & $(-0.558)$ & $(-0.720)$ & \\
\hline$R^{2}$ & 0.150 & 0.151 & 0.151 & 0.151 & 0.179 & 0.014 \\
\hline
\end{tabular}

The table reports coefficient estimates of the following OLS regression:

$$
\text { NetAcq }=\alpha+\beta \times \text { Single }+\gamma \times X+\delta \times Y+\zeta \times(\text { Single } \times \tilde{Y}),
$$

where $N e t A c q$ is acquisitions minus asset sales (scaled by net property, plant \& equipment), Single is a dummy variable equaling one if the CEO is unmarried and zero otherwise, $X$ is a set of firm characteristics, and $Y$ is a set of CEO characteristics (the specific variable definitions are given in Section 2), demeaned when used in interaction terms: $\tilde{Y}=Y-\hat{E} Y$. All specifications also include industry (based on the Fama-French 49-industry classification) and year fixed effects (unreported), with the exception of specification (5), which includes industry $\times$ year fixed effects. T-statistics are in parentheses, and are computed using robust standard errors clustered by firm. 
Table 7: Regression Results for R\&D and Advertising

\begin{tabular}{|c|c|c|c|c|c|c|}
\hline & 1 & 2 & 3 & 4 & 5 & 6 \\
\hline$C F_{t}$ & $\begin{array}{c}0.009 \\
(1.592)\end{array}$ & $\begin{array}{c}0.010 \\
(1.684)\end{array}$ & $\begin{array}{c}0.010 \\
(1.644)\end{array}$ & $\begin{array}{c}0.009 \\
(1.640)\end{array}$ & $\begin{array}{c}0.008 \\
(1.410)\end{array}$ & \\
\hline$M_{t-1} / B_{t-1}$ & $\begin{array}{c}0.015 \\
(2.787)\end{array}$ & $\begin{array}{c}0.013 \\
(2.397)\end{array}$ & $\begin{array}{c}0.012 \\
(2.155)\end{array}$ & $\begin{array}{c}0.012 \\
(2.144)\end{array}$ & $\begin{array}{c}0.012 \\
(2.240)\end{array}$ & \\
\hline $\log A_{t-1}$ & $\begin{array}{c}-0.026 \\
(-6.738)\end{array}$ & $\begin{array}{c}-0.028 \\
(-6.822)\end{array}$ & $\begin{array}{c}-0.033 \\
(-6.739)\end{array}$ & $\begin{array}{c}-0.033 \\
(-6.862)\end{array}$ & $\begin{array}{c}-0.030 \\
(-6.540)\end{array}$ & \\
\hline Leverage $_{t}$ & $\begin{array}{c}-0.019 \\
(-1.125)\end{array}$ & $\begin{array}{l}-0.025 \\
(-1.422)\end{array}$ & $\begin{array}{c}-0.023 \\
(-1.303)\end{array}$ & $\begin{array}{c}-0.023 \\
(-1.304)\end{array}$ & $\begin{array}{c}-0.029 \\
(-1.690)\end{array}$ & \\
\hline Net $A c q_{t-1}$ & $\begin{array}{c}0.806 \\
(39.609)\end{array}$ & $\begin{array}{c}0.800 \\
(38.798)\end{array}$ & $\begin{array}{c}0.799 \\
(38.546)\end{array}$ & $\begin{array}{c}0.799 \\
(38.576)\end{array}$ & $\begin{array}{c}0.801 \\
(39.110)\end{array}$ & \\
\hline FirmAge & $\begin{array}{c}-0.000 \\
(-0.587)\end{array}$ & $\begin{array}{c}0.000 \\
(0.019)\end{array}$ & $\begin{array}{c}0.000 \\
(0.098)\end{array}$ & $\begin{array}{c}0.000 \\
(0.115)\end{array}$ & $\begin{array}{c}-0.000 \\
(-0.310)\end{array}$ & \\
\hline Single & $\begin{array}{c}0.033 \\
(2.598)\end{array}$ & $\begin{array}{c}0.024 \\
(1.932)\end{array}$ & $\begin{array}{c}0.029 \\
(2.402)\end{array}$ & $\begin{array}{c}0.029 \\
(2.228)\end{array}$ & $\begin{array}{c}0.032 \\
(2.590)\end{array}$ & $\begin{array}{c}0.324 \\
(5.667)\end{array}$ \\
\hline Age & & $\begin{array}{c}-0.001 \\
(-1.966)\end{array}$ & $\begin{array}{c}-0.001 \\
(-1.393)\end{array}$ & $\begin{array}{c}-0.001 \\
(-1.395)\end{array}$ & $\begin{array}{c}-0.001 \\
(-2.100)\end{array}$ & $\begin{array}{l}-0.016 \\
(-8.702)\end{array}$ \\
\hline Age $\times$ Single & & $\begin{array}{c}-0.005 \\
(-1.879)\end{array}$ & $\begin{array}{c}-0.005 \\
(-1.886)\end{array}$ & $\begin{array}{l}-0.005 \\
(-1.880)\end{array}$ & $\begin{array}{c}-0.004 \\
(-1.630)\end{array}$ & $\begin{array}{l}-0.024 \\
(-2.478)\end{array}$ \\
\hline Tenure & & $\begin{array}{c}-0.002 \\
(-2.597)\end{array}$ & $\begin{array}{c}-0.002 \\
(-2.769)\end{array}$ & $\begin{array}{c}-0.002 \\
(-2.694)\end{array}$ & $\begin{array}{c}-0.001 \\
(-2.070)\end{array}$ & $\begin{array}{l}-0.003 \\
(-1.143)\end{array}$ \\
\hline Tenure $\times$ Single & & $\begin{array}{c}0.002 \\
(0.541)\end{array}$ & $\begin{array}{c}0.002 \\
(0.475)\end{array}$ & $\begin{array}{c}0.001 \\
(0.446)\end{array}$ & $\begin{array}{c}0.001 \\
(0.240)\end{array}$ & $\begin{array}{c}0.013 \\
(0.713)\end{array}$ \\
\hline CEOProminence & & & $\begin{array}{c}0.009 \\
(3.233)\end{array}$ & $\begin{array}{c}0.009 \\
(3.226)\end{array}$ & $\begin{array}{c}0.009 \\
(3.040)\end{array}$ & $\begin{array}{c}0.016 \\
(2.148)\end{array}$ \\
\hline FirmProminence & & & $\begin{array}{c}0.001 \\
(0.198)\end{array}$ & $\begin{array}{c}0.001 \\
(0.192)\end{array}$ & $\begin{array}{c}0.001 \\
(0.190)\end{array}$ & \\
\hline Inst & & & & $\begin{array}{c}-0.000 \\
(-0.014)\end{array}$ & $\begin{array}{c}-0.003 \\
(-0.130)\end{array}$ & \\
\hline Inst $\times$ Single & & & & $\begin{array}{c}0.032 \\
(0.382) \\
\end{array}$ & $\begin{array}{c}0.031 \\
(0.380) \\
\end{array}$ & \\
\hline$R^{2}$ & 0.765 & 0.761 & 0.761 & $\begin{array}{l}0.761 \\
\end{array}$ & 0.770 & 0.048 \\
\hline
\end{tabular}

The table reports coefficient estimates of the following OLS regression:

$$
R \& D+\text { Advertising }=\alpha+\beta \times \text { Single }+\gamma \times X+\delta \times Y+\zeta \times(\text { Single } \times \tilde{Y}),
$$

where $R \& D+$ Advertising is $\mathrm{R} \& \mathrm{D}$ expenditure plus advertising expenditure (scaled by net property, plant $\&$ equipment), Single is a dummy variable equaling one if the CEO is unmarried and zero otherwise, $X$ is a set of firm characteristics, and $Y$ is a set of CEO characteristics (the specific variable definitions are given in Section 2), demeaned when used in interaction terms: $\tilde{Y}=Y-\hat{E} Y$. All specifications also include industry (based on the Fama-French 49-industry classification) and year fixed effects (unreported), with the exception of specification (5), which includes industry $\times$ year fixed effects. T-statistics are in parentheses, and are computed using robust standard errors clustered by firm. 
Table 8: Effect of Idiosyncratic Risk on Investment: Within-Firm Evidence

\begin{tabular}{|c|c|c|c|c|c|}
\hline & 1 & 2 & 3 & 4 & 5 \\
\hline$C F_{t}$ & & $\begin{array}{c}0.101 \\
(16.110)\end{array}$ & $\begin{array}{c}0.100 \\
(15.850)\end{array}$ & $\begin{array}{c}0.103 \\
(15.590)\end{array}$ & $\begin{array}{c}0.103 \\
(15.600)\end{array}$ \\
\hline$M_{t-1} / B_{t-1}$ & & $\begin{array}{c}0.207 \\
(21.240)\end{array}$ & $\begin{array}{c}0.206 \\
(21.120)\end{array}$ & $\begin{array}{c}0.198 \\
(19.570)\end{array}$ & $\begin{array}{c}0.199 \\
(19.610)\end{array}$ \\
\hline $\log A_{t-1}$ & & $\begin{array}{c}-0.334 \\
(-15.680)\end{array}$ & $\begin{array}{c}-0.341 \\
(-15.960)\end{array}$ & $\begin{array}{c}-0.348 \\
(-15.640)\end{array}$ & $\begin{array}{c}-0.347 \\
(-15.580)\end{array}$ \\
\hline Leverage $_{t}$ & & $\begin{array}{c}0.745 \\
(12.540)\end{array}$ & $\begin{array}{c}0.762 \\
(12.820)\end{array}$ & $\begin{array}{c}0.757 \\
(12.220)\end{array}$ & $\begin{array}{c}0.757 \\
(12.220)\end{array}$ \\
\hline Investment $_{t-1}$ & & $\begin{array}{c}0.082 \\
(12.690)\end{array}$ & $\begin{array}{c}0.082 \\
(12.580)\end{array}$ & $\begin{array}{c}0.074 \\
(10.970)\end{array}$ & $\begin{array}{c}0.074 \\
(10.970)\end{array}$ \\
\hline FirmAge & & $\begin{array}{c}0.043 \\
(14.200)\end{array}$ & $\begin{array}{c}0.038 \\
(11.800)\end{array}$ & $\begin{array}{c}0.038 \\
(10.440)\end{array}$ & $\begin{array}{c}0.039 \\
(10.500)\end{array}$ \\
\hline Single & $\begin{array}{c}-0.043 \\
(-1.090)\end{array}$ & $\begin{array}{c}-0.043 \\
(-1.110)\end{array}$ & $\begin{array}{c}-0.048 \\
(-1.260)\end{array}$ & $\begin{array}{c}-0.037 \\
(-0.900)\end{array}$ & $\begin{array}{c}-0.026 \\
(-0.600)\end{array}$ \\
\hline Age & & & & $\begin{array}{c}-0.003 \\
(-1.600)\end{array}$ & $\begin{array}{c}-0.003 \\
(-1.380)\end{array}$ \\
\hline Age $\times$ Single & & & & & $\begin{array}{c}-0.003 \\
(-0.450)\end{array}$ \\
\hline Tenure & & & & $\begin{array}{c}0.002 \\
(0.620)\end{array}$ & $\begin{array}{c}0.001 \\
(0.170)\end{array}$ \\
\hline Tenure $\times$ Single & & & & & $\begin{array}{c}0.010 \\
(1.220)\end{array}$ \\
\hline CEOProminence & & & $\begin{array}{c}-0.009 \\
(-0.910)\end{array}$ & $\begin{array}{c}-0.019 \\
(-1.730)\end{array}$ & $\begin{array}{c}-0.019 \\
(-1.760)\end{array}$ \\
\hline FirmProminence & & & $\begin{array}{c}-0.016 \\
(-1.050)\end{array}$ & $\begin{array}{c}-0.013 \\
(-0.810)\end{array}$ & $\begin{array}{c}-0.013 \\
(-0.790)\end{array}$ \\
\hline Inst & & & $\begin{array}{c}0.349 \\
(4.950) \\
\end{array}$ & $\begin{array}{c}0.338 \\
(4.660) \\
\end{array}$ & $\begin{array}{c}0.337 \\
(4.650) \\
\end{array}$ \\
\hline$I d V o l_{t-1}$ & $\begin{array}{c}-0.175 \\
(-3.100)\end{array}$ & $\begin{array}{c}-0.330 \\
(-5.940)\end{array}$ & $\begin{array}{c}-0.290 \\
(-5.180)\end{array}$ & $\begin{array}{c}-0.288 \\
(-4.940)\end{array}$ & $\begin{array}{c}-0.289 \\
(-4.950)\end{array}$ \\
\hline$I d V o_{t-1} \times$ Single & $\begin{array}{c}0.216 \\
(2.250)\end{array}$ & $\begin{array}{c}0.309 \\
(3.320)\end{array}$ & $\begin{array}{c}0.291 \\
(3.130)\end{array}$ & $\begin{array}{c}0.312 \\
(3.220)\end{array}$ & $\begin{array}{c}0.319 \\
(3.270)\end{array}$ \\
\hline
\end{tabular}

The table reports coefficient estimates of the following OLS regression:

$$
\text { Investment }_{t}=\alpha+\beta \times \text { Single }+\gamma \times I d \text { Vol }_{t-1}+\delta \times\left(\text { Single } \times I d \widetilde{V o l}_{t-1}\right)+\zeta \times X,
$$

where Investment is our measure of total investment in Table 5 and $X$ is a set of firm and CEO characteristics. All variables are demeaned when used in interaction terms (e.g.: $\left.I d \widetilde{V o l}_{t-1}=I d V o l_{t-1}-\hat{E} I d V o l_{t-1}\right)$. All specifications also include firm and year fixed effects (unreported). T-statistics are in parentheses. 
Table 9: Validating the Instrument: Marital Status and Divorce Law in the U.S.

\begin{tabular}{lcccc}
\hline \hline & 1 & 2 & 3 & 4 \\
\hline Intercept & 1.252 & 1.185 & 1.182 & 1.181 \\
& $(260.000)$ & $(220.560)$ & $(220.160)$ & $(219.970)$ \\
Comm & -0.007 & -0.007 & -0.007 & -0.007 \\
& $(-5.730)$ & $(-4.330)$ & $(-4.180)$ & $(-4.190)$ \\
Income & -0.415 & -1.374 & -1.274 & -1.240 \\
& $(-38.130)$ & $(-79.080)$ & $(-83.330)$ & $(-82.170)$ \\
Age & -0.037 & -0.031 & -0.031 & -0.031 \\
& $(-205.780)$ & $(-142.400)$ & $(-142.480)$ & $(-142.440)$ \\
Age & 0.027 & 0.030 & 0.030 & 0.030 \\
& $(177.880)$ & $(152.280)$ & $(152.430)$ & $(152.380)$ \\
Occ & & & -0.005 & -0.084 \\
& & & $(-0.680)$ & $(-10.790)$ \\
\hline Comm $\times$ Income & 0.193 & 0.349 & & \\
Comm $\times$ Occ & $(9.390)$ & $(11.070)$ & & \\
& & & 0.041 & 0.018 \\
& & & $(3.090)$ & $(1.280)$ \\
\hline
\end{tabular}

This table presents the results of an OLS regressions of marital status on measures of income as well as their interactions with the legal regime guiding division of marital assets in divorce in the state of residence, controlling for age, using the data from the 2000 U.S. Census $5 \%$ sample from the Integrated Public Use Microdata Series (IPUMS). The regression specification is

Single $=\alpha+\beta \times C o m m+\gamma \times$ Income $+\delta \times A g e+\zeta \times \frac{A g e^{2}}{100}+\eta \times$ Occ $+\chi \times$ Income $\times C o m m+\kappa \times \widetilde{\text { Occ }} \times$ Comm,

where Comm is the dummy variable equal to one if the household's state of residence is a community property state. Single is a dummy variable equal to one if the head of household has never been married (specification 1) or has never been married, is divorced, or is widowed (specifications 2-4). Income is in millions. Occ is a dummy variable for whether the head of household is either a lawyer or a surgeon/physician by occupation (specification 3) or a chief executive (specification 4). The interacted variables Income and $\widetilde{O C C}$ are demeaned using population weights. T-statistics are reported in the parentheses. 
Table 10: Predicting CEO Marital Status with Divorce Law Instrument

\begin{tabular}{|c|c|c|c|c|c|c|}
\hline & 1 & 2 & 3 & 4 & 5 & 6 \\
\hline Community & $\begin{array}{c}0.050 \\
(3.740)\end{array}$ & $\begin{array}{c}0.048 \\
(3.510)\end{array}$ & $\begin{array}{c}0.049 \\
(3.610)\end{array}$ & $\begin{array}{c}0.049 \\
(3.580)\end{array}$ & $\begin{array}{c}0.059 \\
(4.410)\end{array}$ & $\begin{array}{c}0.046 \\
(3.250)\end{array}$ \\
\hline$C F_{t}$ & $\begin{array}{c}-0.006 \\
(-1.860)\end{array}$ & $\begin{array}{c}-0.003 \\
(-0.930)\end{array}$ & $\begin{array}{c}-0.003 \\
(-0.870)\end{array}$ & $\begin{array}{c}-0.003 \\
(-0.910)\end{array}$ & & $\begin{array}{c}-0.001 \\
(-0.320)\end{array}$ \\
\hline$M_{t-1} / B_{t-1}$ & $\begin{array}{c}-0.008 \\
(-2.170)\end{array}$ & $\begin{array}{c}-0.001 \\
(-0.260)\end{array}$ & $\begin{array}{c}0.001 \\
(0.340)\end{array}$ & $\begin{array}{c}0.001 \\
(0.330)\end{array}$ & & $\begin{array}{c}0.001 \\
(0.290)\end{array}$ \\
\hline $\log A_{t-1}$ & $\begin{array}{c}-0.041 \\
(-11.050)\end{array}$ & $\begin{array}{c}-0.027 \\
(-7.000)\end{array}$ & $\begin{array}{c}-0.016 \\
(-3.710)\end{array}$ & $\begin{array}{c}-0.017 \\
(-3.910)\end{array}$ & & $\begin{array}{l}-0.016 \\
(-3.670)\end{array}$ \\
\hline Leverage $_{t-1}$ & $\begin{array}{c}0.018 \\
(0.800)\end{array}$ & $\begin{array}{c}-0.010 \\
(-0.410)\end{array}$ & $\begin{array}{c}-0.014 \\
(-0.620)\end{array}$ & $\begin{array}{c}-0.015 \\
(-0.640)\end{array}$ & & $\begin{array}{c}-0.011 \\
(-0.480)\end{array}$ \\
\hline$I d V o l_{t-1}$ & $\begin{array}{c}0.037 \\
(1.740)\end{array}$ & $\begin{array}{l}0.020 \\
(0.870)\end{array}$ & $\begin{array}{c}0.029 \\
(1.320)\end{array}$ & $\begin{array}{c}0.031 \\
(1.440)\end{array}$ & & $\begin{array}{c}0.035 \\
(1.620)\end{array}$ \\
\hline Investment $_{t-1}$ & $\begin{array}{c}0.009 \\
(2.950)\end{array}$ & $\begin{array}{c}0.008 \\
(2.640)\end{array}$ & $\begin{array}{c}0.008 \\
(2.820)\end{array}$ & $\begin{array}{c}0.008 \\
(2.800)\end{array}$ & & $\begin{array}{c}0.008 \\
(2.640)\end{array}$ \\
\hline FirmAge & $\begin{array}{c}-0.001 \\
(-3.260)\end{array}$ & $\begin{array}{c}-0.002 \\
(-3.840)\end{array}$ & $\begin{array}{c}-0.002 \\
(-3.730)\end{array}$ & $\begin{array}{c}-0.002 \\
(-3.670)\end{array}$ & & $\begin{array}{l}-0.002 \\
(-3.680)\end{array}$ \\
\hline Age & & $\begin{array}{c}-0.002 \\
(-2.900)\end{array}$ & $\begin{array}{c}-0.003 \\
(-3.780)\end{array}$ & $\begin{array}{c}-0.003 \\
(-3.760)\end{array}$ & $\begin{array}{c}-0.004 \\
(-5.450)\end{array}$ & $\begin{array}{c}-0.003 \\
(-4.050)\end{array}$ \\
\hline Tenure & & $\begin{array}{c}-0.002 \\
(-1.400)\end{array}$ & $\begin{array}{c}-0.002 \\
(-1.350)\end{array}$ & $\begin{array}{c}-0.002 \\
(-1.330)\end{array}$ & $\begin{array}{c}-0.002 \\
(-1.430)\end{array}$ & $\begin{array}{c}-0.002 \\
(-1.630)\end{array}$ \\
\hline Wealth & & $\begin{array}{c}-0.021 \\
(-7.220)\end{array}$ & $\begin{array}{c}-0.017 \\
(-5.810)\end{array}$ & $\begin{array}{c}-0.017 \\
(-5.780)\end{array}$ & $\begin{array}{c}-0.020 \\
(-7.250)\end{array}$ & $\begin{array}{c}-0.019 \\
(-6.180)\end{array}$ \\
\hline CEOProminence & & & $\begin{array}{c}-0.021 \\
(-5.370)\end{array}$ & $\begin{array}{c}-0.021 \\
(-5.370)\end{array}$ & $\begin{array}{c}-0.031 \\
(-10.570)\end{array}$ & $\begin{array}{l}-0.022 \\
(-5.610)\end{array}$ \\
\hline FirmProminence & & & $\begin{array}{c}-0.003 \\
(-0.720)\end{array}$ & $\begin{array}{c}-0.002 \\
(-0.710)\end{array}$ & & $\begin{array}{l}-0.002 \\
(-0.660)\end{array}$ \\
\hline Inst & & & & $\begin{array}{c}0.040 \\
(1.540)\end{array}$ & & $\begin{array}{c}0.033 \\
(1.300)\end{array}$ \\
\hline Payroll & & & & & & $\begin{array}{c}0.069 \\
(0.100)\end{array}$ \\
\hline$C E A I$ & & & & & & $\begin{array}{c}-0.121 \\
(-0.280)\end{array}$ \\
\hline LogIncomeState & & & & & & $\begin{array}{c}0.055 \\
(1.200)\end{array}$ \\
\hline$\overline{R^{2}}$ & $\begin{array}{l}0.09 \\
\end{array}$ & 0.10 & 0.11 & 0.11 & $\begin{array}{l}0.09 \\
\end{array}$ & 0.11 \\
\hline
\end{tabular}

The table reports coefficient estimates of the following OLS regression:

$$
\text { Single }=\alpha+\beta \times \text { Community }+\gamma \times X+\delta \times Y+\zeta \times Z \text {, }
$$

where Single is a dummy variable equaling one if the CEO is unmarried and zero otherwise, Community is a dummy variable equaling one if the firm is headquartered in a community property state and zero otherwise, $X$ is a set of firm characteristics, $Y$ is a set of CEO characteristics, and $Z$ is a set of state-level control variables (the specific variable definitions are given in Sections 2 and 4.3). All specifications also include industry (based on the Fama-French 49-industry classification) and year fixed effects (unreported). T-statistics are in parentheses, and are computed using robust standard errors clustered by state. 
Table 11: IV Results for Idiosyncratic Volatility

\begin{tabular}{|c|c|c|c|c|c|c|}
\hline & 1 & 2 & 3 & 4 & 5 & 6 \\
\hline$C F_{t}$ & $\begin{array}{c}-0.003 \\
(-3.210)\end{array}$ & $\begin{array}{c}-0.003 \\
(-3.270)\end{array}$ & $\begin{array}{c}-0.004 \\
(-3.470)\end{array}$ & $\begin{array}{c}-0.003 \\
(-3.260)\end{array}$ & & $\begin{array}{c}-0.004 \\
(-3.830)\end{array}$ \\
\hline$M_{t-1} / B_{t-1}$ & $\begin{array}{c}0.003 \\
(1.810)\end{array}$ & $\begin{array}{c}0.002 \\
(1.130)\end{array}$ & $\begin{array}{c}0.001 \\
(0.580)\end{array}$ & $\begin{array}{c}0.001 \\
(0.660)\end{array}$ & & $\begin{array}{c}0.001 \\
(0.520)\end{array}$ \\
\hline $\log A_{t-1}$ & $\begin{array}{c}-0.015 \\
(-3.340)\end{array}$ & $\begin{array}{c}-0.017 \\
(-4.920)\end{array}$ & $\begin{array}{c}-0.022 \\
(-7.760)\end{array}$ & $\begin{array}{c}-0.020 \\
(-7.290)\end{array}$ & & $\begin{array}{c}-0.020 \\
(-7.490)\end{array}$ \\
\hline Leverage $_{t}$ & $\begin{array}{c}0.077 \\
(11.500)\end{array}$ & $\begin{array}{c}0.078 \\
(11.180)\end{array}$ & $\begin{array}{c}0.079 \\
(10.990)\end{array}$ & $\begin{array}{c}0.080 \\
(10.920)\end{array}$ & & $\begin{array}{c}0.079 \\
(11.330)\end{array}$ \\
\hline$I d V o l_{t-1}$ & $\begin{array}{c}0.331 \\
(7.610)\end{array}$ & $\begin{array}{c}0.330 \\
(7.020)\end{array}$ & $\begin{array}{c}0.326 \\
(6.910)\end{array}$ & $\begin{array}{c}0.321 \\
(6.730)\end{array}$ & & $\begin{array}{c}0.318 \\
(6.670)\end{array}$ \\
\hline FirmAge & $\begin{array}{c}-0.000 \\
(-1.970)\end{array}$ & $\begin{array}{c}-0.000 \\
(-1.370)\end{array}$ & $\begin{array}{c}-0.000 \\
(-1.540)\end{array}$ & $\begin{array}{c}-0.000 \\
(-1.590)\end{array}$ & & $\begin{array}{c}-0.000 \\
(-1.460)\end{array}$ \\
\hline SinglePred & $\begin{array}{c}0.297 \\
(2.680)\end{array}$ & $\begin{array}{c}0.308 \\
(2.480)\end{array}$ & $\begin{array}{c}0.301 \\
(2.570)\end{array}$ & $\begin{array}{c}0.316 \\
(2.560)\end{array}$ & $\begin{array}{c}0.643 \\
(2.660)\end{array}$ & $\begin{array}{c}0.330 \\
(2.730)\end{array}$ \\
\hline Age & & $\begin{array}{c}-0.000 \\
(-0.330)\end{array}$ & $\begin{array}{c}0.000 \\
(0.380)\end{array}$ & $\begin{array}{c}0.000 \\
(0.390)\end{array}$ & $\begin{array}{c}0.000 \\
(0.140)\end{array}$ & $\begin{array}{c}0.000 \\
(0.470)\end{array}$ \\
\hline Tenure & & $\begin{array}{c}0.000 \\
(1.130)\end{array}$ & $\begin{array}{c}0.000 \\
(0.980)\end{array}$ & $\begin{array}{c}0.000 \\
(0.960)\end{array}$ & $\begin{array}{c}0.001 \\
(1.800)\end{array}$ & $\begin{array}{c}0.001 \\
(1.400)\end{array}$ \\
\hline Wealth & & $\begin{array}{c}0.003 \\
(0.980)\end{array}$ & $\begin{array}{c}0.001 \\
(0.480)\end{array}$ & $\begin{array}{c}0.001 \\
(0.460)\end{array}$ & $\begin{array}{c}0.000 \\
(0.080)\end{array}$ & $\begin{array}{c}0.002 \\
(0.710)\end{array}$ \\
\hline CEOProminence & & & $\begin{array}{c}0.010 \\
(4.410)\end{array}$ & $\begin{array}{c}0.011 \\
(4.390)\end{array}$ & $\begin{array}{c}0.013 \\
(1.910)\end{array}$ & $\begin{array}{c}0.011 \\
(4.540)\end{array}$ \\
\hline FirmProminence & & & $\begin{array}{c}-0.000 \\
(-0.300)\end{array}$ & $\begin{array}{c}-0.000 \\
(-0.350)\end{array}$ & & $\begin{array}{l}-0.000 \\
(-0.350)\end{array}$ \\
\hline Inst & & & & $\begin{array}{c}-0.075 \\
(-4.880)\end{array}$ & & $\begin{array}{l}-0.075 \\
(-5.000)\end{array}$ \\
\hline Payroll & & & & & & $\begin{array}{c}0.108 \\
(0.350)\end{array}$ \\
\hline$C E A I$ & & & & & & $\begin{array}{c}0.190 \\
(0.640)\end{array}$ \\
\hline LogIncomeState & & & & & & $\begin{array}{c}0.003 \\
(0.190)\end{array}$ \\
\hline$R^{2}$ & 0.443 & 0.442 & 0.442 & 0.444 & 0.301 & 0.444 \\
\hline
\end{tabular}

The table reports coefficient estimates of the following OLS regression:

$$
I d V o l=\alpha+\beta \times \text { SinglePred }+\gamma \times X+\delta \times Y+\zeta \times Z,
$$

where $I d V o l$ is the annualized standard deviation of residuals from the regression of firm monthly stock returns on the market return, SinglePred is the predicted value for Single computed using coefficient estimates for the corresponding specification in Table 10, $X$ is a set of firm characteristics, $Y$ is a set of $\mathrm{CEO}$ characteristics, and $Z$ is a set of state-level control variables (the specific variable definitions are given in Sections 2 and 4.3). All specifications also include industry (based on the Fama-French 49-industry classification) and year fixed effects (unreported). T-statistics are in parentheses, and are computed using robust standard errors clustered by state, taking into account the uncertainty in first-stage estimates. 
Table 12: IV Results for Total Investment

\begin{tabular}{|c|c|c|c|c|c|c|}
\hline & 1 & 2 & 3 & 4 & 5 & 6 \\
\hline \multirow{2}{*}{$C F_{t}$} & 0.109 & 0.109 & 0.108 & 0.108 & & 0.109 \\
\hline & (6.110) & $(5.350)$ & $(5.410)$ & $(5.370)$ & & $(5.600)$ \\
\hline \multirow{2}{*}{$M_{t-1} / B_{t-1}$} & 0.135 & 0.103 & 0.096 & 0.096 & & 0.096 \\
\hline & (9.940) & $(7.890)$ & $(7.850)$ & $(7.870)$ & & $(7.070)$ \\
\hline \multirow[t]{2}{*}{$\log A_{t-1}$} & -0.030 & -0.083 & -0.122 & -0.123 & & -0.128 \\
\hline & $(-0.800)$ & $(-2.980)$ & $(-5.890)$ & $(-5.840)$ & & $(-6.440)$ \\
\hline \multirow[t]{2}{*}{ Leverage $_{t}$} & 0.148 & 0.245 & 0.255 & 0.255 & & 0.292 \\
\hline & $(2.330)$ & $(4.550)$ & $(4.900)$ & $(4.920)$ & & $(5.420)$ \\
\hline \multirow{2}{*}{ Investment $_{t-1}$} & 0.470 & 0.464 & 0.463 & 0.463 & & 0.456 \\
\hline & $(18.890)$ & $(20.690)$ & $(20.220)$ & $(20.160)$ & & $(18.780)$ \\
\hline \multirow[t]{2}{*}{ FirmAge } & 0.001 & 0.002 & 0.002 & 0.002 & & 0.003 \\
\hline & $(0.720)$ & $(1.200)$ & $(1.200)$ & $(1.210)$ & & $(1.610)$ \\
\hline \multirow[t]{2}{*}{ SinglePred } & 2.299 & 2.197 & 2.114 & 2.107 & 5.367 & 2.357 \\
\hline & $(2.560)$ & $(2.260)$ & $(2.440)$ & $(2.380)$ & $(1.880)$ & $(2.990)$ \\
\hline \multirow[t]{2}{*}{ Age } & & -0.003 & -0.001 & -0.001 & -0.005 & -0.000 \\
\hline & & $(-1.130)$ & $(-0.350)$ & $(-0.350)$ & $(-0.450)$ & $(-0.080)$ \\
\hline \multirow[t]{2}{*}{ Tenure } & & -0.003 & -0.004 & -0.004 & 0.001 & -0.003 \\
\hline & & $(-0.910)$ & $(-1.180)$ & $(-1.170)$ & $(0.250)$ & $(-1.130)$ \\
\hline \multirow[t]{2}{*}{ Wealth } & & 0.073 & 0.059 & 0.059 & 0.155 & 0.071 \\
\hline & & $(3.600)$ & $(3.690)$ & $(3.690)$ & $(2.670)$ & $(4.280)$ \\
\hline \multirow[t]{2}{*}{ CEOProminence } & & & 0.076 & 0.075 & 0.134 & 0.076 \\
\hline & & & $(4.210)$ & $(4.150)$ & $(1.610)$ & $(4.930)$ \\
\hline \multirow[t]{2}{*}{ FirmProminence } & & & 0.004 & 0.004 & & 0.009 \\
\hline & & & $(0.360)$ & $(0.360)$ & & $(0.830)$ \\
\hline \multirow[t]{2}{*}{ Inst } & & & & 0.020 & & 0.047 \\
\hline & & & & $(0.190)$ & & $(0.570)$ \\
\hline \multirow[t]{2}{*}{ Payroll } & & & & & & 0.641 \\
\hline & & & & & & $(0.270)$ \\
\hline \multirow[t]{2}{*}{$C E A I$} & & & & & & -1.448 \\
\hline & & & & & & $(-0.770)$ \\
\hline \multirow[t]{2}{*}{ LogIncomeState } & & & & & & 0.285 \\
\hline & & & & & & $(2.300)$ \\
\hline$R^{2}$ & 0.446 & 0.445 & 0.445 & 0.445 & 0.170 & 0.450 \\
\hline
\end{tabular}

The table reports coefficient estimates of the following OLS regression:

$$
\text { Investment }=\alpha+\beta \times \text { SinglePred }+\gamma \times X+\delta \times Y+\zeta \times Z \text {, }
$$

where Investment is capital expenditures plus acquisitions minus asset sales plus R\&D expenditure plus advertising expenditure (scaled by net property, plant \& equipment), SinglePred is the predicted value for Single computed using coefficient estimates for the corresponding specification in Table 10, $X$ is a set of firm characteristics, $Y$ is a set of CEO characteristics, and $Z$ is a set of state-level control variables (the specific variable definitions are given in Sections 2 and 4.3). All specifications also include industry (based on the Fama-French 49-industry classification) and year fixed effects (unreported). T-statistics are in parentheses, and are computed using robust standard errors clustered by state, taking into account the uncertainty in first-stage estimates. 